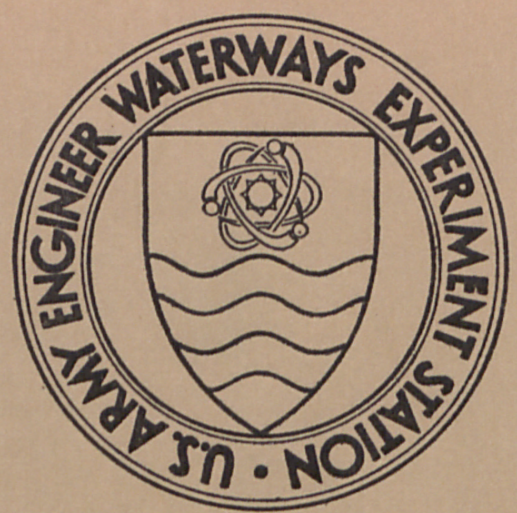

MISCELLANEOUS PAPER S-70-14

\title{
EVALUATION OF SOIL STRENGTH OF UNSURFACED FORWARD-AREA AIRFIELDS BY USE OF GROUND VEHICLES
}

by

G. M. Hammitt II

RESEARCH GENTER LIBRARY

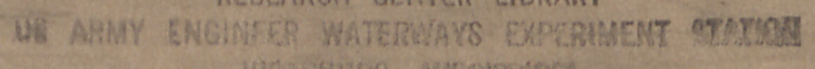

May 1970

Sponsored by Office, Chief of Engineers, U. S. Army

Conducted by U. S. Army Engineer Waterways Experiment Station, Vicksburg, Mississippi 


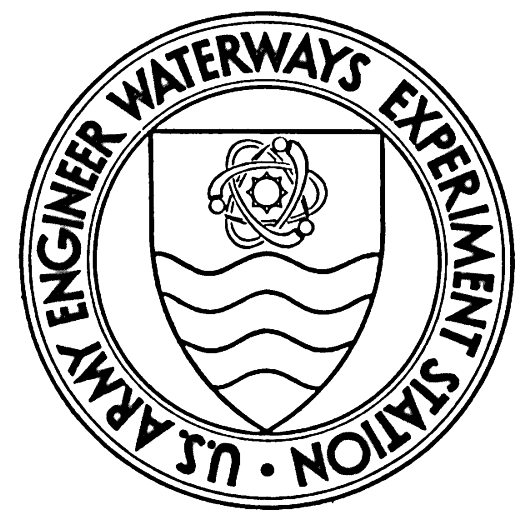

MISCELLANEOUS PAPER S-70-14

\section{EVALUATION OF SOIL STRENGTH OF UNSURFACED FORWARD-AREA AIRFIELDS BY USE OF GROUND VEHICLES \\ by}

G. M. Hammitt II

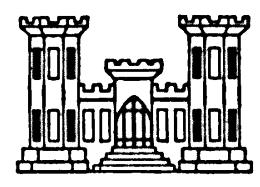

May 1970

Sponsored by Office, Chief of Engineers, U. S. Army

Conducted by U. S. Army Engineer Waterways Experiment Station, Vicksburg, Mississippi 


\section{Foreword}

This study was authorized by the office, chicf of linerineers, in "Instructions and Outline for Technical Support - Army, FY 1967," dated May 1966. The Flexible Pavement Branch, Soils Division, U. S. Army Engineer Waterways Experiment Station (WES), conducted this study for the Civil Engineering Branch, Engineering Division, Military Construction, Office, Chief of Engineers.

This study was conducted during the period September-November 1967 under the supervision of Messrs. W. J. Turnbull, Chief, and A. A. Maxwell, Assistant Chief, Soils Division, WES. Engineers of the WES Soils Division actively concerned with the planning, testing, analyzing, and reporting phases of this study were Messrs. R. G. Ahilvin, D. N. Brown, and G. M. Hammitt II. This report was prepared by Mr. Hammitt.

Directors of the WES during the conduct of the study and the preparation of this report were COI John R. Oswalt, Jr., CE, and COL Levi A. Brown, CE. Technical Directors were Mr. J. B. Tiffany and Mr. F. R. Brown. 


\section{Contents}

Pare

Foreword . . . . . . . . . . . . . . . . . $\mathrm{i} i \mathrm{i}$

Conversion F'actors, British to Metric Units of Measurement . . . . . vii Summary . . . . . . . . . . . . . . . . . . ix Introduction ...................... 1 Background .................... I Objective and scope of study .............. I Terminology. . . . . . . . . . . . . . 2 Office study ........................ 3 Data sources .................. 3 Validation Tests . . . . . . . . . . . . . . . . 6

Field tests. . . . . . . . . . . . . . 6

Test and test results.'................ 7

Comparison of office study results with field results. . . . . 9 Conclusions and Recommendations. . . . . . . . . . . . . 9

Conclusions. . . . . . . . . . . . . . . . . 9 Recommendations................. 9 Literature Cited . . . . . . . . . . . . . . . 9 Tables 1 and 2 .

Photographs 1-5

Plates 1-13

Appendix A: Application of Soil Strength Assessment Method. . . . . Al Table AI 
Conversion Factors, British to Metric Units of Measurement

British units of measurement used in this report cur be converted to metric units as follows:

Multiply

inches

feet

square inches

pounds

tons

kips

pounds per square inch miles per hour
By

2.54

0.3048

6.4516

0.45359237

907.185

453.59231

0.070307

$1.60931 / 4$
To Obtain

centimeters

meters

square centimeters

kilograms

kilograms

kilograms

kilograms per square centimeter kilometers per hour 


\section{Summary}

This report describes a method for rapidly determining the soil strength at forward-area airfields. Through the use of dimensionless ground mobility parameters developed by the U. S. Army Engineer Waterways Experiment Station, soil strength indications are determined by measuring rut depths created by traffic of standard military ground vehicles. This method enables reasonably accurate assessment of' soil strength by personnel without special training and without the use of special instruments. If the soil strength existing in the forward areas is known, predictions can be made concerning the ability of a particular site to sustain specific aircraft traffic.

Initially, an office study was conducted that established the potential of such a method. Then limited field verification tests were conducted with four standard military ground vehicles, i.e. a 1/4-ton Ml51, a 3/4-ton $\mathrm{MB} 7$, a 2-1/2-ton M35Al, and a 5-ton M55, operated on a prepared unsurfaced heavy clay subgrade with a strength of approximately 2 CBR . First-pass rut depths were measured for each vehicle operated empty and for all but the M55 with maximum cross-country loading.

The results of this testing indicated the feasibility of predicting soil strength based on one-pass rut depth caused by military ground vehicles. This method can be used to predict the ability of a particular forward-area airfield to sustain specific small aircraft traffic. It is recommended that further studies include operations of aircraft from actual landing sites on both clay and sand. 
EVALUATION OF SOIL S'I'RENGTH OF UNSURFACED

FORWARD-AREA AIRFIELDS BY USE OF GROUND VEHICLES

\section{Introduction}

\section{Background}

1. Recommended soil strength criteria for airfields in the theater of operations are presented in Department of the Army Technical Manual 5-330. I These criteria áre in the form of design curves for paved and unpaved soil surfaces. The design curves are based on the CBR test for soil strength. Evaluation of soil strength by the CBR test requires trained personnel, special test equipment, certain laboratory facilities, and an amount of time that is dependent on the scope of the survey. The time, however, car be reduced significantly through use of the cone penetrometer. Reference $I$ provides for use of the cone penetrometer as an expedient in lieu of the CBR test, thus eliminating the need for laboratory facilities and reducing the equipment and time requirements. However, the cone penetrometer test still requires special equipment and a minimum amount of training for the tester. Therefore, there is a critical need for a method by which a reasonabiy accurate assessment of soil strength can be rapidly made without the use of any special instruments by personnel without special training, particularly to aid in the selection of forward-area airfield sites to be used for short periods of time. Objective and scope of study

2. Objective. The objective of this study was to establish a method of rapidly assessing initial soil strength or changes in soil strength at existing fields as a result of rainfall. This method would be used in connection with selection of sites for forward-area airfields and would eliminate requirements for specially trained personnel, special test equipment, and laboratory facilities. Rapid survey of entire landing strip areas would be possible with less effort involved than that involved in surveys using the cone penetrometer or CBR method.

3. Scope. The initial program consisted of using existing research data to make certain predictions as to the ability of a particular site to 
sustain specific aircraft traffic. This program produced results relating the operation of several standard military ground vehicles to requirements for operation of military aircraft on unsurfaced fields. These results were tabulated as the final product of the office study, but because of certain areas in which inadequate correlative data existed, elements of engineering judgment were involved in the tabulation. Thus, a field test effort was made to validate the reliability of the initial scheme or to provide a basis for its adjustment to a final satisfactory site assessment system. The field testing consisted of trafficking an existing section at the U. S. Army Engineer Waterways Experiment Station (WES) with four military ground vehicles. The four vehicles consisted of a 1/4-ton* MI5I truck, a 3/4-ton M37 truck, a 2-1/2-ton M35AI truck, and a 5-ton M55 truck. The large-scale test facility allowed the four military ground vehicles to traffic the section at approximately. $5 \mathrm{mph}$. Cross sections and cone index data were taken prior to traffic and after one pass of each vehicle. Rut depth measurements were made at selected points in the tracks at the rear of the test vehicle. Dimensionless ground mobility parameter predictions were compared with the data taken.

4. The tabulated results for application of the method of rapid soil strength determination presented herein are given in Appendix A. This appendix shows the allowable coverages for example aircraft based on one-pass rut depths of four standard military ground vehicles.

Terminology

5. For information and clarity, definitions of certain terms used in this report are given below:

California Bearing Ratio (CBR). A measure of the bearing capacity of the soil based upon its shearing resistance. The CBR is calculated by.dividing the unit load required to force a piston into the soil by the unit load required to force the same piston the same depth into a standard sample of crushed stone and multiplying by $100 .^{2}$

Cone Index (CI). The cone index is an index of soil consistency or strength. It is the force required to push a 30-deg right circular cone

* A table of factors for converting British units of measurement to metric units is presented on page vii. 
of 0.5 -sq-in. base area through the soil at a rate of 72 in. per min. ${ }^{3}$ Alrfield Index (AI). The airfield index is an index of soil consistency or strength. It is the force required to push a 30-deg right circular cone of 0.2-sq-in. base area through the soil at a rate of 72 in. per min.

\section{Office Study}

Data sources

6. Ground-flotation study. The one-pass rut depth data used for this study were obtained partly from accelerated traffic tests conducted by the WES to establish ground-flotation criteria for the operation of aircraft on unsurfaced soils. Complete information on this test program can be found in reference 5 .

7. To establish the desired criteria, test sections were constructed of heavy clay (CH). Classification data for the soils used in test sections are shown in plate I. A typical test section consisted of several test items, each with a different subgrade strength. Each item was divided into traffic lanes, and traffic tests were conducted on the controlledstrength subgrades with load carts equipped with single- or multiple-wheel assemblies and with a range of tire sizes, wheel loads, and tire inflation pressures. All traffic data were obtained on unsodded test items. As reported previously, ${ }^{6}$ sod provides strength benefits of such small magnitude that it represents no practical differential.

8. Model tests. Data from model tests conducted at WES with pneumatic tires in soft soils were also utilized. These model tests were conducted in soil carts. The soils and methods of soil preparation used are described in detail in WES Technical Report No. 3-688. ${ }^{7}$ Classification data for the soil are shown in plate 2.

9. Input data. In both investigations described above, soil strength measurements were obtained with the standard in-place CBR apparatus described in reference 2. CBR, water content, and density determinations were made at the surface and at 6- and 12-in. depths in each test item just prior to and at the conclusion of traffic. Deformation measurements indicating the total sinkage from the original ground surface were 
also made. For the purpose of this study, only single-wheel, initial-pass. data were considered. These data and measurements were used as described later. The dimensionless ground mobility parameters were developed from the tests described in reference 7 . However, the validity of the tests described in reference 7 was never verified for the type of study reported herein. That is, the results of the model tests reported in reference 7 were not related to the operation of full-scale vehicles. Analysis of data

10. Dimensionless ground mobility parameters. To accomplish the objective of this study, the dimensionless ground mobility parameters developed at WES were employed. These parameters consist of clay and sand mobility numbers that reduce the variables of wheel load, soil strength, tire size, and tire deflection into a dimensionless ratio of soil and. wheel. characteristics in the manners shown below.

Clay mobility number (CMN):

$$
\mathrm{CMN}=\frac{\mathrm{CIbd}}{\mathrm{W}} \times\left(\frac{\delta}{\mathrm{h}}\right)^{1 / 2}
$$

Sand mobility number (SMN):

$$
\mathrm{SMN}=\frac{\mathrm{G}(\mathrm{bd})^{3 / 2}}{\mathrm{~W}} \times \frac{\delta}{\mathrm{h}}
$$

Sinkage number (SN):

$$
\mathrm{SN}=\mathrm{z} / \mathrm{d}
$$

where

$$
\begin{aligned}
\mathrm{CI}= & \text { cone index } \\
\mathrm{b}= & \text { cross-sectional width of tire, in. } \\
\mathrm{d}= & \text { outside diameter of tire, in. } \\
\mathrm{W}= & \text { vertical wheel load, lb } \\
\delta= & \text { tire deflection (difference between heights of loaded and } \\
& \text { unloaded sections) } \\
\mathrm{h}= & \text { tire section height, in. }
\end{aligned}
$$


$\mathrm{G} \stackrel{=}{=}$ cone index gradient (avernge incrente in (y per inch over : depth equal to the tire width)

$z=$ one-pass rut depth, in.

Some of these terms are illustrated in plate 3.

11. A plot showing the relation of sinkage number to clay mobility number is. shown in plate 4. This relation should be used in all site evaluations except those involving a clean, cohesionless, free-draining sand. A plot of the sinkage number versus sand mobility number is also shown in plate 4. A comparison study showed close agreement between the relation of sinkage number and clay mobility number as established by small wheels and light load tests and ground-flotation tests with full-scale wheels and loads (plate 5 ).

12. The soil-strength variable can be expressed in terms of CBR, CI, or AI (see plate 6). CI can be converted to AI by dividing the CI by 50 .

13. Application. As previously stated, the standard military ground vehicles chosen for the study reported herein were the 1/4-ton MI5I, the 3/4-ton M37, the 2-1/2-ton M34, and the 5-ton M55 trucks. Using the empty and loaded front-wheel loads and tire dimensions, data were calculated for a soil strength versus rut depth curve for each vehicle. The front-wheel loads were used because the ground mobility parameters were developed for front-wheel loading only. The dimensionless ground mobility parameters were employed to reduce the variables of wheel load and tire dirensions and to produce the data presented in table 1 and the plots shown in plates 7-10. Similar plots could be prepared for any pneumatic-tired ground vehicle at any loading. After the front tire one-pass rut depth of a particular military ground vehicle has been measured, the approximate soil strength can be determined from an appropriate plot of cone index versus rut depth. With this strength determination, the feasibility of a given aircraft operating at a site can be predicted (see plate 11).

14. Sample problem: Determine if a C-7A aircraft having a singlewheel load of 6.4 kips and tire inflation pressure of $39 \mathrm{psi}$ can successfully operate on a clay site where a l-in. rut depth resulted from one pass of the front wheel of a 2-1/2-ton M34 cargo truck.

Solution: The empty M34 cargo truck has a front axle weight of 
$6900 \mathrm{lb}$ and an $11.00 \times 20$ tire size. With a one-pass rut depth of 1 in., the sinkage number $\mathrm{z} / \mathrm{d}$ for this vehicle would be 0.023 . From plate 4 , the clay mobility number is 5.60. By substitution in equation $I$ as shown below, the strength of the soil in terms of CI would be 93 .

$$
\begin{aligned}
& 5.6=\frac{C I \times 12.04 \times 43.2}{3450} \times 0.16^{I / 2} \\
& 5.6=\frac{520.1 \mathrm{CI}}{3450} \times 0.4 \\
& 5.6=0.06 \mathrm{CI} \\
& \mathrm{CI}=93 ; \mathrm{AI}=1.9
\end{aligned}
$$

Next, by entering the nomograph (plate 1I) with the C-7A load of $6.4 \mathrm{kips}$ and tire pressure of $39 \mathrm{psi}$ and the soil strength (1.9 AI), it is determined that the C-7A cannot successfully operate on this particular landing site.

\section{Validation Tests}

15. The results of the office study indicated the potential use of the dimensional analysis technique in predicting soil strength from rut depths and it was decided to validate this conclusion by a limited field study.

Field tests

16. Test section. The field traffic tests were conducted at WES on a special test section constructed under shelter. A general view of the test section prior to traffic is shown in photograph 1 . The test bin was approximately $12 \mathrm{ft}$ wide, $170 \mathrm{ft}$ long, and $5 \mathrm{ft}$ deep. The heavy clay soil was placed in the 5-ft-deep test bin in 6-in. lifts. Compaction was performed with a self-propelled pneumatic-tired roller loaded to approximately $30,000 \mathrm{lb}$. The soil had a liquid limit of 58 and a plasticity index of 31 and was classified as clay (CH). The gradation curve for the heavy clay soil is shown in plate 1 . The clay was identical with that used to provide 
the input data for the predictions made in the office study. A summary of strength data for the surface of the section before traffic is given in. table 2 .

17. Test loads and vehicles. One-pass traffic was applied to the test section with the vehicles described in the following tabulation:

\begin{tabular}{|c|c|}
\hline Vehicle & $\begin{array}{c}\text { Weight } \\
\text { Ib }\end{array}$ \\
\hline $\begin{array}{l}\text { 1/4-ton MI5I } \\
\text { Empty } \\
\text { Max cross-country load }\end{array}$ & $\begin{array}{l}2,635 \\
3,035\end{array}$ \\
\hline $\begin{array}{l}\text { 3/1-ton } M B 7 \\
\text { Empty } \\
\text { Max cross-country load }\end{array}$ & $\begin{array}{l}6,010 \\
7,820\end{array}$ \\
\hline $\begin{array}{l}\text { 2-I/2-ton M35AI } \\
\text { Empty } \\
\text { Max cross-country load }\end{array}$ & $\begin{array}{l}13,500 \\
18,500\end{array}$ \\
\hline -ton M5 & \\
\hline
\end{tabular}

All vehicles were operated at approximately $5 \mathrm{mph}$. The vehicle characteristics are documented in Ordnance Tank Automotive Command, Section S..V-I dated January $1967 .^{8}$ All trucks used the tire size and pressure recommended by the Ordnance Tank Automotive Command. Weights were approximately the same as those recommended by the manufacturer. All computations were based on manufacturer's values listed in table 1.

Test and test results

18. A summary of the test data, including soil strength ( $C I$ and $C B R$ ) and rut depth, is presented in table 2. Cross sections of the test section at different stations prior to traffic are shown in plate 12. The M51, M37, and M35Al each made one pass down the test section empty. The three vehicles then made one pass with the maximum cross-country load. The M55 trafficked the section at a weight of $20,500 \mathrm{lb}$. Each vehicle was-positioned to traffic fresh soil each time.

19. Operation 1. The empty 1/4-ton MI5I (weight 2635 lb) traversed the prepared test section. Cross sections after one pass are shown in plate 12. Photograph 2 shows the section after one pass of the empty MI5I vehicle. The rut depth measured an average of 0.10 in. excluding upheaval and 0.11 in. including upheaval. 
20. Operation 2. An empty MB7 truck (weight $6010 \mathrm{lb}$ ) trafficked the test section next. Cross sections after one pass are shown in plate 12. Photograph 3 shows the section after one pass of the empty MB7 vehicle. The rut depth measured an average of 0.43 in. excluding upheaval and 0.55 in. including upheaval.

21. Operation 3. An empty 2-1/2-ton M35Al vehicle (weight 13,500 Ib) trafficked the test section next. Cross sections after one pass are shown in plate 12. Photograph 4 shows the section after one pass of the MB5Al. The rut depth measured an average of 0.51 in. excluding upheaval and 0.96 in. including upheaval. The test section was planed to remove ruts. Cross sections after planing are shown in plate 13.

22. Operation 4. A loaded 1/4-ton MI5I vehicle with a weight of 3035 Ib trafficked the test section. Photograph $5 \mathrm{a}$ shows the test section after one pass of the loaded MI5l. The rut depth measured an average of 0.16 in. excluding upheaval and $0.28 \mathrm{in.}$ including upheaval. Cross sections at various stations are shown in plate 13.

23. Operation 5. Next, a 3/4-ton MB7 vehicle with a gross weight of $7800 \mathrm{Ib}$ trafficked the test section. Photograph $5 \mathrm{~b}$ shows the test section after one pass of the loaded M37, and cross sections are shown in plate 13. The rut depth measured an average of $0.60 \mathrm{in}$. excluding upheaval and 1.09 in. including upheaval.

24. Operation 6. A 5-ton M55 vehicle with a gross weight of 20,500 Ib trafficked the test section next. Photograph $5 \mathrm{c}$ shows the test section after one pass of the empty M55 vehicle. The rut depth measured an average of $0.57 \mathrm{in.} \mathrm{excluding} \mathrm{upheaval} \mathrm{and} 1.34 \mathrm{in}$. including upheaval. The test section was planed to remove ruts. The cross sections after one pass of the empty M55 vehicle are shown in plate 13.

25. Operation 7. Next, a 2-1/2-ton M35Al vehicle with a gross weight of 18,500 $\mathrm{Ib}$ trafficked the test section. Photograph $5 \mathrm{~d}$ shows the test section after one pass of the loaded M35AI vehicle. The rut depth measured an average of $1.0 \mathrm{in}$. excluding upheaval and $1.86 \mathrm{in.}$ including upheaval.

26. After completion of testing, CBR's at sta $10+00$ and $25+00$ were 1.8 and 2.0 , respectively. 
27. Table 2 shows a comparison of the predicted and measured rut depths. These data indicate that the rut depths in the clay soil were predicted.with a remarkable degree of accuracy.

\section{Conclusions and Recommendations}

\section{Conclusions}

28. The dimensionless ground mobility parameters developed at WES for small towed model tires can be applied with reasonable accuracy to the prediction of soil strength based on one-pass rut depth caused by several standard military ground vehicles.

29. A plot of rut depth versus soil strength can be developed for any pneumatic-tired ground vehicle with any loading.

30. The method presented in this report can be used to predict the ability of a particular forward-area airfield to sustain specific small aircraft traffic. It should be noted, however, that this study was limited to cohesive soils.

Recommendations

31. A study is needed to verify predictions for a sand surface.

32. A field test with specific aircraft and ground vehicles is needed for a minimum of two sites, one sand site and one clay site.

33. Further study is needed to determine if this method or similar methods could be developed to predict rut depth or deflections for various other surfaces.

\section{Literature Cited}

1. Headquarters, Department of the Army, "Planning and Design of Roads, Airbases, and Heliports in the Theater of Operations," Technical Manual 5-330, Sept 1968, Washington, D. C.

2. U. S. Department of Defense, "Test Methods for Pavement Subgrade, Subbase, and Base-Course Materials," MIL-STD-621A, Dec 1964, U. S. Government Printing Office, Washington, D. C. 
3. Headquarters, Department of the Army, "Soils Trafficability," Technical Bulletin ENG-37, July 1959, Washington, D. C.

4. Fenwick, W. B., "Description and Application of Airfield Cone Penetrometer," Instruction Report No. 7, Oct 1965, U. S. Army Engineer Waterways Experiment Station, CE, Vicksburg, Miss.

5. Ladd, D. M. and Ulery, H. H., Jr., "Aircraft Ground-Flotation Investigation; Part 1--Basic Report," Technical Report No. 3-737, Aug 1967, U. S. Army Engineer Waterways Experiment Station, CE, Vicksburg, Miss.

6. Womack, L. M., "Traffic Tests to Determine the Benefits of Vegetation in Increasing Traffic Coverages," Miscellaneous Paper No. 4-769, Dec 1965, U. S. Army Engineer Waterways Experiment Station, CE, Vicksburg, Miss.

7. Freitag, D. R., "A Dimensional Analysis of the Performance of Pneumatic Tires on Soft Soils," Technical Report No. 3-688, Aug 1965, U. S. Army Engineer Waterways Experiment Station, $\mathrm{CE}$, Vicksburg, Miss.

8. Headquarters, Department of the Army, "Military Tactical Vehicles (Ordnance Corps Responsibility)," Technical Manual 9-236, Sept 1960, Washington, D. C. 
Table 1

Determination of Soll Strength from Rut Depth for a Clay So11

\begin{tabular}{|c|c|c|c|c|c|c|c|c|c|}
\hline Vehicle & $\begin{array}{c}\text { Vehicle } \\
\text { Welght } \\
1 b\end{array}$ & $\begin{array}{l}\text { Tire } \\
\text { Size }\end{array}$ & $\begin{array}{l}\text { Unloaded } \\
\text { Outside } \\
\text { Tire } \\
\text { Diam (d) } \\
\text { In. } \\
\end{array}$ & $\begin{array}{c}\text { Tire } \\
\text { Pressure } \\
\text { psi } \\
\end{array}$ & $\begin{array}{l}\text { Unloaded } \\
\text { Tire } \\
\text { Width (b) } \\
\text { In. } \\
\end{array}$ & $\begin{array}{c}\text { Rut } \\
\text { Depth }(z) \\
\text { In. }\end{array}$ & $\begin{array}{c}\text { Sinkage } \\
\text { Coefflcient } \\
\text { 2/d } \\
\end{array}$ & $\begin{array}{c}\text { Clay } \\
\text { Mobility } \\
\text { No. } \\
\end{array}$ & $\begin{array}{l}\text { Cone } \\
\text { Index } \\
\end{array}$ \\
\hline \multirow[t]{2}{*}{$\begin{array}{l}\text { 1/4-ton, } \\
4 x^{4} \text { Mns truck }\end{array}$} & $\begin{array}{c}2,473 \\
\text { Empty with } \\
\text { driver }\end{array}$ & $7: 00 \times 16$ & 30.5 & 20 & 7.17 & $\begin{array}{c}0 \\
\text { Trace }(0.1) \\
0.25 \\
0.50 \\
1.0 \\
2.0 \\
3.0\end{array}$ & $\begin{array}{l}0.0000 \\
0.0033 \\
0.0082 \\
0.0163 \\
0.0327 \\
0.0657 \\
0.0983\end{array}$ & $\begin{array}{r}>20.00 \\
10.00 \\
7.70 \\
6.00 \\
4.00 \\
3.00 \\
2.75\end{array}$ & $\begin{array}{r}165 \\
82 \\
63 \\
49 \\
33 \\
24 \\
\cdots\end{array}$ \\
\hline & $\begin{array}{c}3,000 \\
\text { Driver and } 3 \\
\text { passengers }\end{array}$ & & & & & $\begin{array}{c}0 \\
\text { Trace }(0.1) \\
0.25 \\
0.50 \\
1.0 \\
2.0 \\
3.0\end{array}$ & $\begin{array}{l}0.0000 \\
0.0033 \\
0.0082 \\
0.0163 \\
0.0327 \\
0.0657 \\
0.0983\end{array}$ & $\begin{array}{r}>20.00 \\
10.00 \\
7.70 \\
6.00 \\
4.00 \\
3.00 \\
2.75\end{array}$ & $\begin{array}{r}200 \\
100 \\
77 \\
60 \\
40 \\
30 \\
-7\end{array}$ \\
\hline \multirow[t]{2}{*}{$\begin{array}{l}3 / 4-\text { ton, } \\
4 \times 4 \mathrm{M} 37 \text { truck }\end{array}$} & Empty & $9: 00 \times 16$ & 35.2 & 50 & 9.63 & $\begin{array}{c}0 \\
\text { Trace }(0.1) \\
0.25 \\
0.50 \\
1.0 \\
2.0 \\
4.0\end{array}$ & $\begin{array}{l}0.0000 \\
0.0028 \\
0.0071 \\
0.0142 \\
0.0282 \\
0.0568 \\
0.1132\end{array}$ & $\begin{array}{r}>20.00 \\
11.00 \\
8.00 \\
6.00 \\
4.25 \\
3.10 \\
2.60\end{array}$ & $\begin{array}{r}250 \\
133 \\
97 \\
73 \\
51 \\
33 \\
31\end{array}$ \\
\hline & $\begin{array}{c}7,820 \\
\text { Gross weight }\end{array}$ & & & & & $\begin{array}{c}0 \\
\text { Trace }(0.1) \\
0.25 \\
0.50 \\
1.0 \\
2.0 \\
4.0\end{array}$ & $\begin{array}{l}0.0000 \\
0.0028 \\
0.0071 \\
0.0142 \\
0.0282 \\
0.0568 \\
0.1132\end{array}$ & $\begin{array}{r}>20.00 \\
11.00 \\
8.00 \\
6.00 \\
4.25 \\
3.10 \\
2.60\end{array}$ & $\begin{array}{r}265 \\
140 \\
102 \\
76 \\
54 \\
40 \\
33\end{array}$ \\
\hline \multirow[t]{2}{*}{$\begin{array}{l}\text { 2-1/2-ton, } \\
6 \times 6 \mathrm{M} 34 \text { truck }\end{array}$} & Empty & 11:00x20 & 43.2 & 75 & 22.04 & $\begin{array}{c}0 \\
\text { Trace }(0.1) \\
0.25 \\
0.5 \\
1.0 \\
2.0 \\
4.0 \\
6.0\end{array}$ & $\begin{array}{l}0.0000 \\
0.0023 \\
0.0057 \\
0.0115 \\
0.0231 \\
0.0462 \\
0.0925 \\
0.1388\end{array}$ & $\begin{array}{r}>20.00 \\
11.50 \\
9.00 \\
6.50 \\
4.75 \\
3.50 \\
2.75 \\
2.50\end{array}$ & $\begin{array}{r}300 \\
182 \\
142 \\
103 \\
75 \\
55 \\
43 \\
39\end{array}$ \\
\hline & $\begin{array}{l}24,300 \\
\text { Gross we1ght }\end{array}$ & $\cdot$ & & & & $\begin{array}{c}0 \\
\text { Trace }(0.1) \\
0.25 \\
0.5 \\
1.0 \\
2.0 \\
4.0 \\
6.0\end{array}$ & $\begin{array}{l}0.0000 \\
0.0023 \\
0.0057 \\
0.0115 \\
0.0231 \\
0.0462 \\
0.0925 \\
0.1388\end{array}$ & $\begin{array}{r}>20.00 \\
11.50 \\
9.00 \\
6.50 \\
4.75 \\
3.50 \\
2.75 \\
2.50\end{array}$ & $\begin{array}{r}350 \\
218 \\
171 \\
123 \\
90 \\
66 \\
52 \\
\ldots\end{array}$ \\
\hline \multirow[t]{2}{*}{$\begin{array}{l}\text { 5-ton, } \\
6 \times 6 \text { M55 truck }\end{array}$} & Empty & U:00x20 & 43.2 & 75 & 12.04 & $\begin{array}{c}0 \\
\text { Trace }(0.1) \\
0.25 \\
0.50 \\
1.0 \\
2.0 \\
4.0 \\
6.0\end{array}$ & $\begin{array}{l}0.0000 \\
0.0023 \\
0.0057 \\
0.0115 \\
0.0231 \\
0.0462 \\
0.0925 \\
0.1388\end{array}$ & $\begin{array}{r}>20.00 \\
11.50 \\
9.00 \\
6.50 \\
4.75 \\
3.50 \\
2.75 \\
2.50\end{array}$ & $\begin{array}{r}400 \\
249 \\
195 \\
141 \\
103 \\
76 \\
60 \\
54\end{array}$ \\
\hline & $\begin{array}{c}34,064 \\
\text { Gross we1ght }\end{array}$ & & - & & 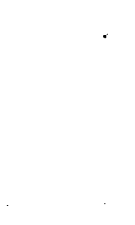 & $\begin{array}{c}0 \\
\text { Trace }(0.1) \\
0.25 \\
0.50 \\
1.0 \\
2.0 \\
4.0 \\
6.0\end{array}$ & $\begin{array}{l}0.0000 \\
0.0023 \\
0.0057 \\
0.0115 \\
0.0231 \\
0.0462 \\
0.0925 \\
0.1388\end{array}$ & $\begin{array}{r}>20.00 \\
11.50 \\
9.00 \\
6.50 \\
4.75 \\
3.50 \\
2.75 \\
2.50\end{array}$ & $\begin{array}{r}400 \\
249 \\
195 \\
141 \\
103 \\
76 \\
60 \\
54\end{array}$ \\
\hline
\end{tabular}


Summary of Data

\begin{tabular}{|c|c|c|c|c|c|c|c|c|c|}
\hline \multicolumn{4}{|c|}{ Vehicle } & \multicolumn{2}{|c|}{$\begin{array}{l}\text { Strength } \\
\text { of Soll } \\
\end{array}$} & \multirow[b]{2}{*}{ Sta } & \multicolumn{2}{|c|}{$\begin{array}{l}\text { Measured Rut } \\
\text { Depth, in. }\end{array}$} & \multirow[b]{2}{*}{$\begin{array}{l}\text { Predicted } \\
\text { Rut Depth } \\
\text { in. } \\
\end{array}$} \\
\hline Type & $\begin{array}{l}\text { Load } \\
\text { Ib }\end{array}$ & $\begin{array}{c}\text { T1re } \\
\text { Pressure } \\
\text { psi } \\
\end{array}$ & Tire Size & $\begin{array}{l}\text { of So } \\
\text { Surface } \\
\text { CI }\end{array}$ & CBR & & $\begin{array}{l}\text { From } \\
\text { Original } \\
\text { Surface } \\
\end{array}$ & Maximum & \\
\hline \multirow[t]{4}{*}{$\begin{array}{l}1 / 4-\text { ton, } 4 \times 4 \\
\text { MISI truck }\end{array}$} & 2,635 & $\begin{array}{l}18 \text { front } \\
22 \text { rear }\end{array}$ & $7: 00 \times 16$ & $\begin{array}{l}63 \\
71 \\
63\end{array}$ & $\begin{array}{l}1.8 \\
1.2 \\
0.8\end{array}$ & $\begin{array}{l}10+\infty 0 \\
15+00 \\
20+\infty 0 \\
25+\infty \\
30+\infty 0 \\
35+\infty\end{array}$ & $\begin{array}{l}0.05 \\
0.12 \\
0.10 \\
0.10 \\
0.10 \\
0.10\end{array}$ & $\begin{array}{l}0.05 \\
0.12 \\
0.10 \\
0.10 \\
0.15 \\
0.15\end{array}$ & \\
\hline & & & & & & Avg & 0.10 & 0.11 & 0.10 \\
\hline & 3,035 & $\begin{array}{l}18 \text { front } \\
22 \text { rear }\end{array}$ & $7: 00 \times 16$ & $\begin{array}{l}78 \\
78 \\
78 \\
76 \\
66\end{array}$ & & $\begin{array}{l}10+\infty \\
15+\infty \\
20+\infty \\
25+\infty \\
30+\infty\end{array}$ & $\begin{array}{l}0.30 \\
0.13 \\
0.05 \\
0.15 \\
0.15\end{array}$ & $\begin{array}{l}0.40 \\
0.20 \\
0.22 \\
0.15 \\
0.45\end{array}$ & \\
\hline & & & & & & Avg & 30.16 & 0.28 & 0.22 \\
\hline \multirow[t]{4}{*}{$\begin{array}{l}\text { 3/4-ton, } 4 \times 4 \\
\text { MB7 truck }\end{array}$} & 6,010 & 40 & $9: 00 \times 16$ & $\begin{array}{l}63 \\
72 \\
63\end{array}$ & & $\begin{array}{l}10+00 \\
15+\infty 0 \\
20+\infty 0 \\
25+\infty 0 \\
30+\infty 0 \\
35+\infty 0\end{array}$ & $\begin{array}{l}0.37 \\
0.47 \\
0.45 \\
0.47 \\
0.40 \\
0.40\end{array}$ & $\begin{array}{l}0.50 \\
0.50 \\
0.55 \\
0.50 \\
0.55 \\
0.70\end{array}$ & . \\
\hline & & & & & & Avg & 0.43 & 0.55 & 0.40 \\
\hline & 7,800 & 40 & $9: 00 \times 16$ & $\begin{array}{l}78 \\
78 \\
78 \\
76 \\
66\end{array}$ & & $\begin{array}{l}10+\infty 0 \\
15+\infty \\
20+\infty \\
25+\infty \\
30+\infty 0\end{array}$ & $\begin{array}{l}0.70 \\
0.40 \\
0.57 \\
0.70 \\
0.63\end{array}$ & $\begin{array}{l}1.27 \\
0.90 \\
1.10 \\
1.10 \\
1.10\end{array}$ & \\
\hline & & & & & & Avg & g 0.60 & 1.09 & 0.45 \\
\hline \multirow[t]{4}{*}{$\begin{array}{l}2-1 / 2-\text { ton, } 6 \times 6 \\
\text { NB5Al truck } \\
\text { W/W }\end{array}$} & 13,500 & 35 & $11: 00 \times 20$ & $\begin{array}{l}63 \\
72 \\
63\end{array}$ & & $\begin{array}{l}10+\infty 0 \\
15+\infty 0 \\
20+\infty 0 \\
25+\infty 0 \\
30+\infty 0\end{array}$ & $\begin{array}{l}0.60 \\
0.54 \\
0.47 \\
0.50 \\
0.45\end{array}$ & $\begin{array}{l}1.00 \\
1.00 \\
0.95 \\
0.80 \\
1.05\end{array}$ & \\
\hline & & & & & & Avg & 80.51 & 0.96 & $\begin{array}{l}1.05 \\
0.90^{*}\end{array}$ \\
\hline & 18,500 & 35 & 11:00x20 & $\begin{array}{l}80 \\
80 \\
72 \\
62\end{array}$ & & $\begin{array}{l}12+\infty 0 \\
17+\infty 0 \\
22+\infty 0 \\
27+\infty\end{array}$ & $\begin{array}{l}1.12 \\
0.92 \\
0.91 \\
1.05\end{array}$ & $\begin{array}{l}1.95 \\
1.68 \\
1.83 \\
2.00\end{array}$ & \\
\hline & & & & & & $A v_{B}$ & $8 \quad 1.00$ & 1.86 & $\begin{array}{l}1.60 \\
1.30 *\end{array}$ \\
\hline \multirow[t]{2}{*}{$\begin{array}{l}\text { 5-ton, } 6 \times 6 \\
\text { M55 truck }\end{array}$} & 20,500 & 35 & 11:00x20 & $\begin{array}{l}78 \\
78 \\
78 \\
76\end{array}$ & $\begin{array}{l}1.8 \\
2.0\end{array}$ & $\begin{array}{l}10+\infty 0 \\
15+\infty \\
20+\infty 0 \\
25+\infty 0\end{array}$ & $\begin{array}{l}0.65 \\
0.52 \\
0.65 \\
0.45\end{array}$ & $\begin{array}{l}1.58 \\
1.25 \\
1.50 \\
1.05\end{array}$ & \\
\hline & & & & & & $A v B$ & 80.57 & 1.34 & 1.30 \\
\hline
\end{tabular}

* Predicted rut depth based on pertinent $\mathrm{M}^{\prime}$ 2-1/2-ton vehicle characteristics. 


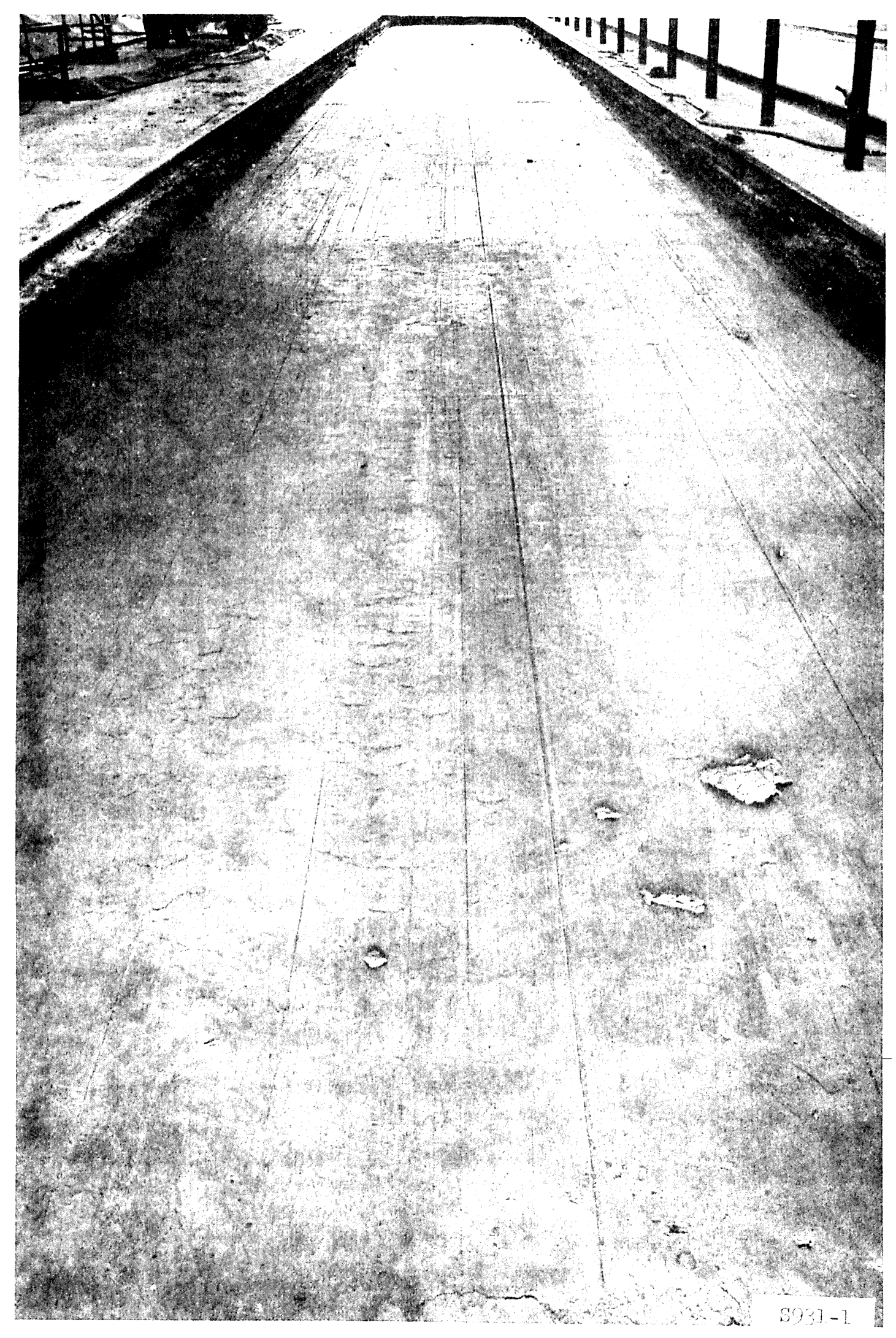

Photorraph 1. Test section prior to traperc 


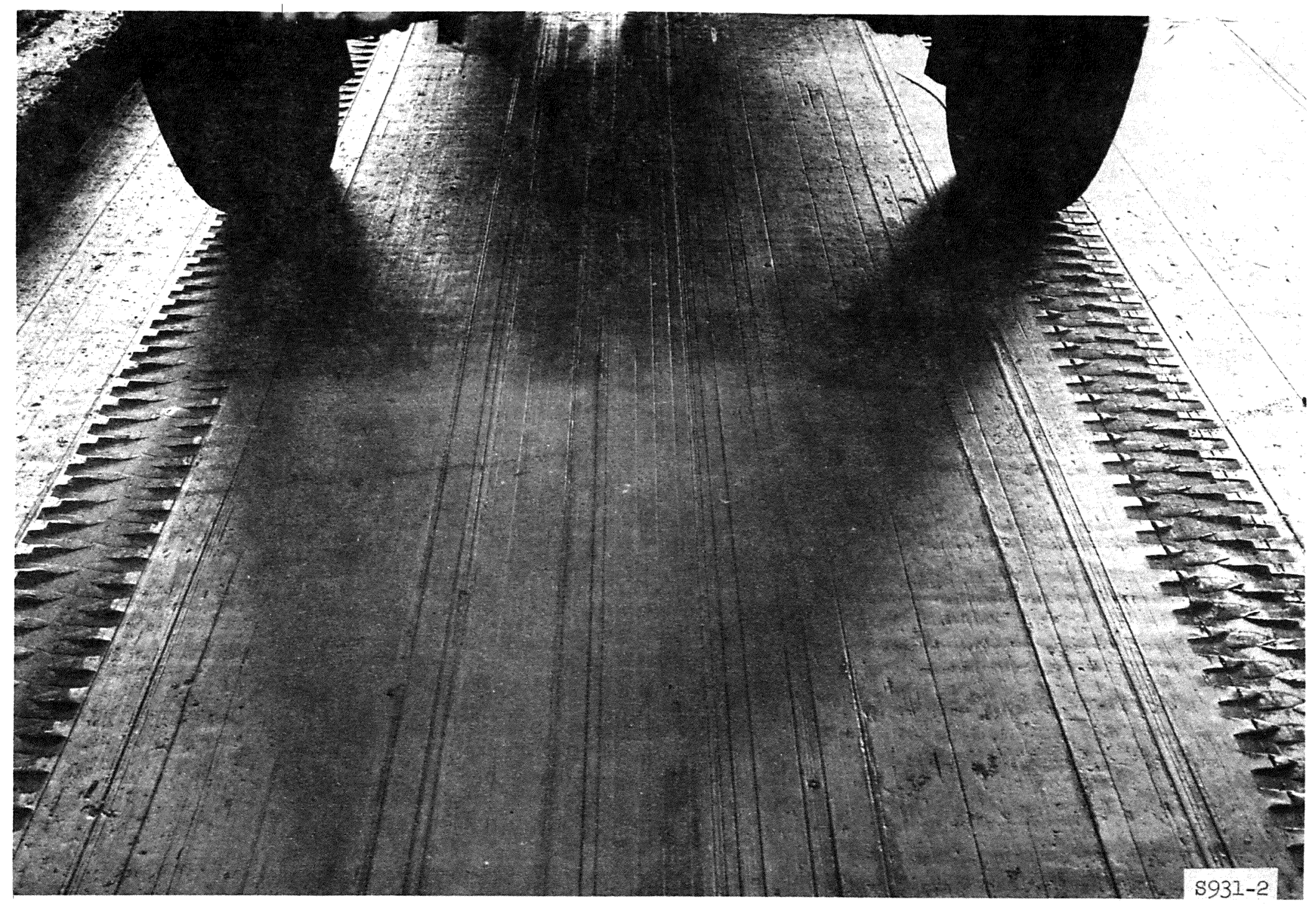

Photograph 2. Ruts resulting from one pass of the empty 1/4-ton MI5I truck 


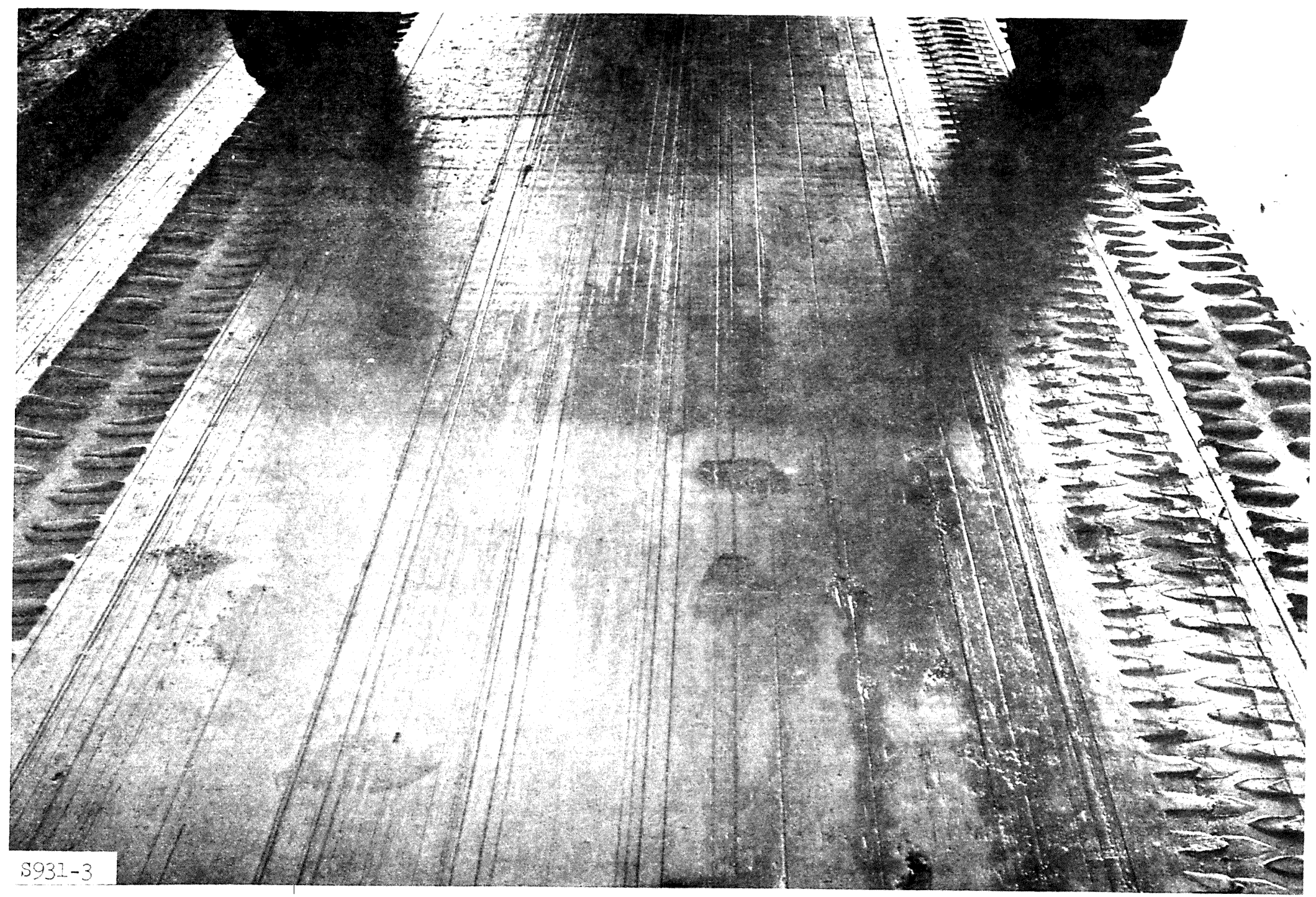

Photograph 3. Rut (at far right) resulting from one pass of the empty 3/4-ton M37 truck 


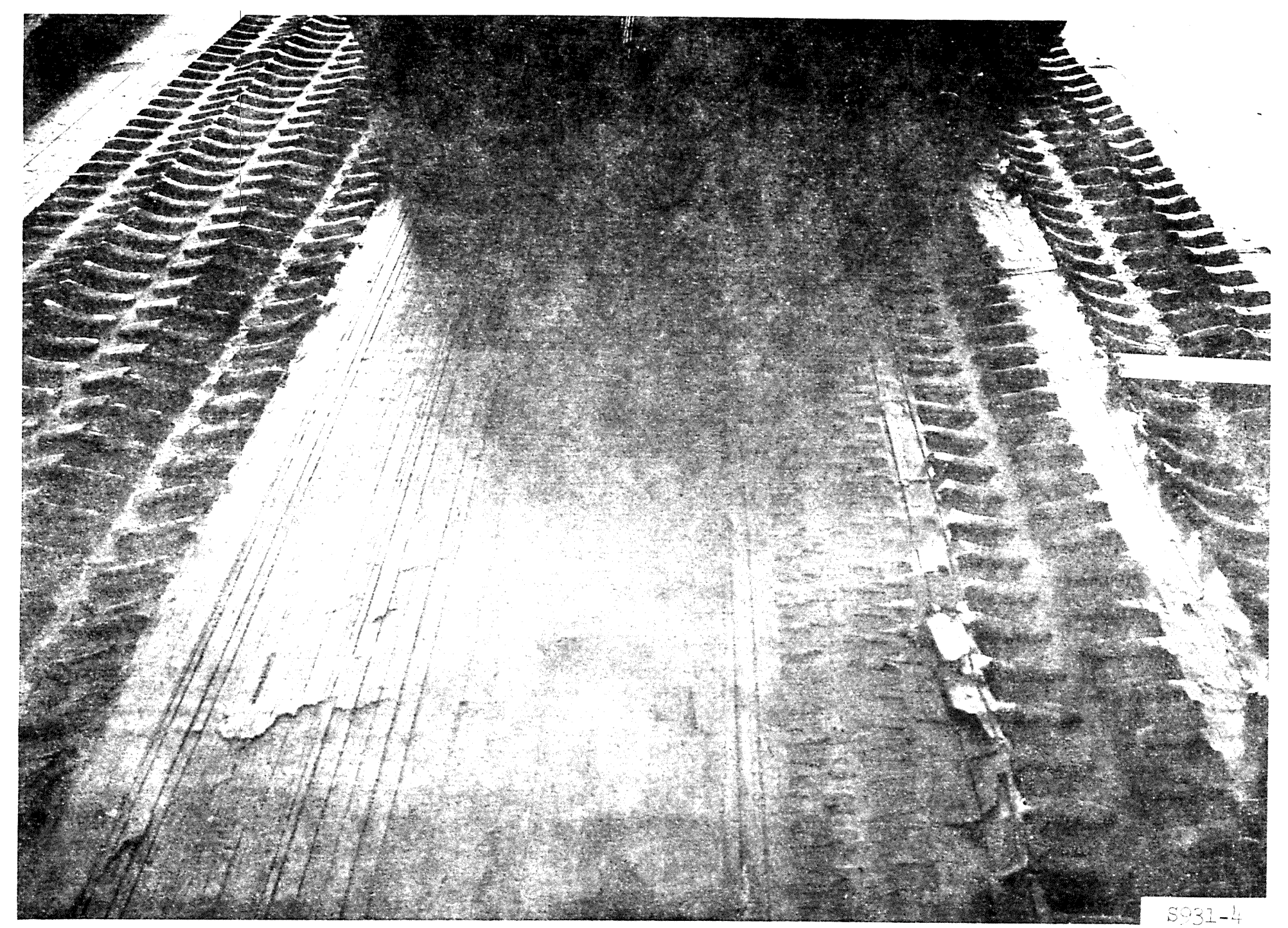

Photomaph 4. Ruts resulting from one pass of the empty 2-1/2-ton M35 and other vehicles. Rule at right marks print of the rear tire of the MBSAI 


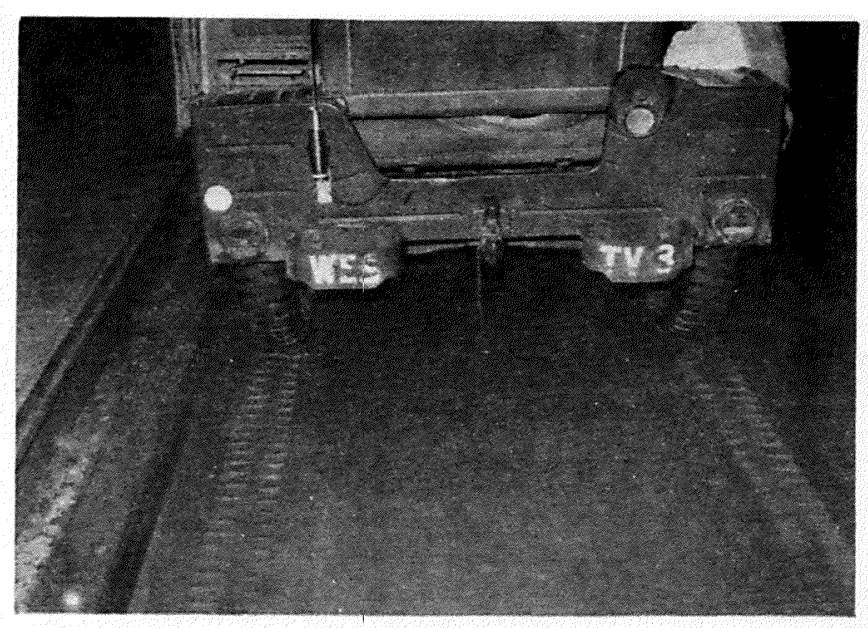

a. Loaded MI5I

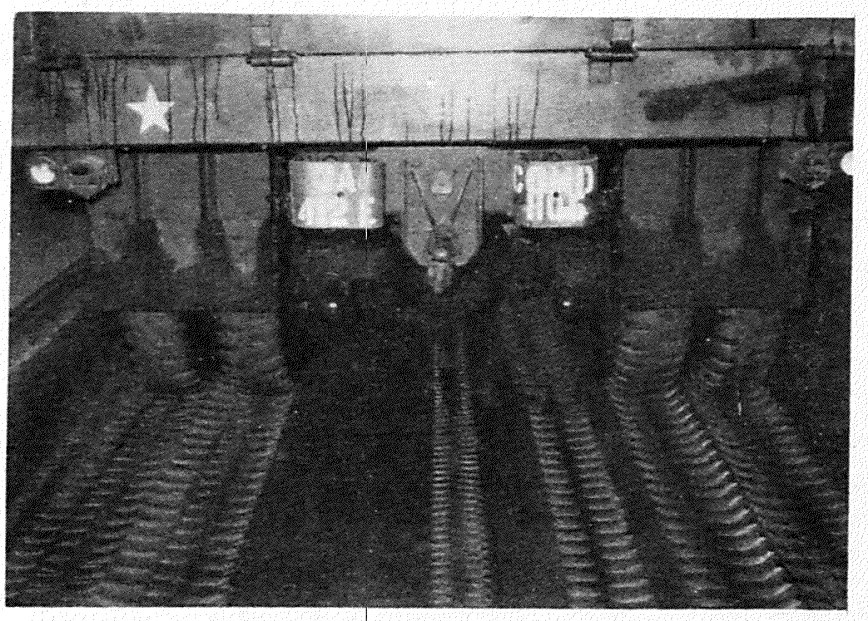

c. Empty M55

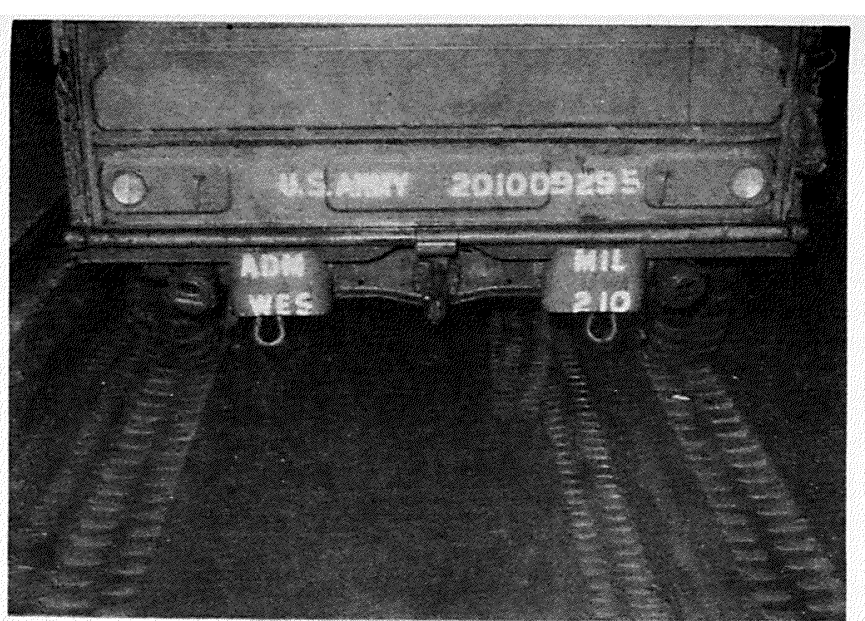

b. Loaded M37

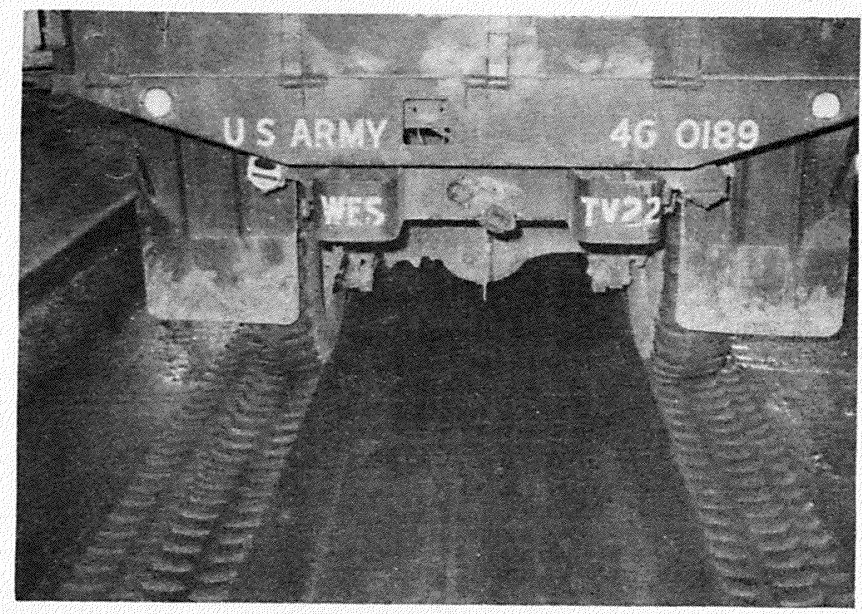

d. Loaded M35AI

Photograph 5. Ruts from traffic of various test vehicles. Rut made in untrafficked soil used for analysis 


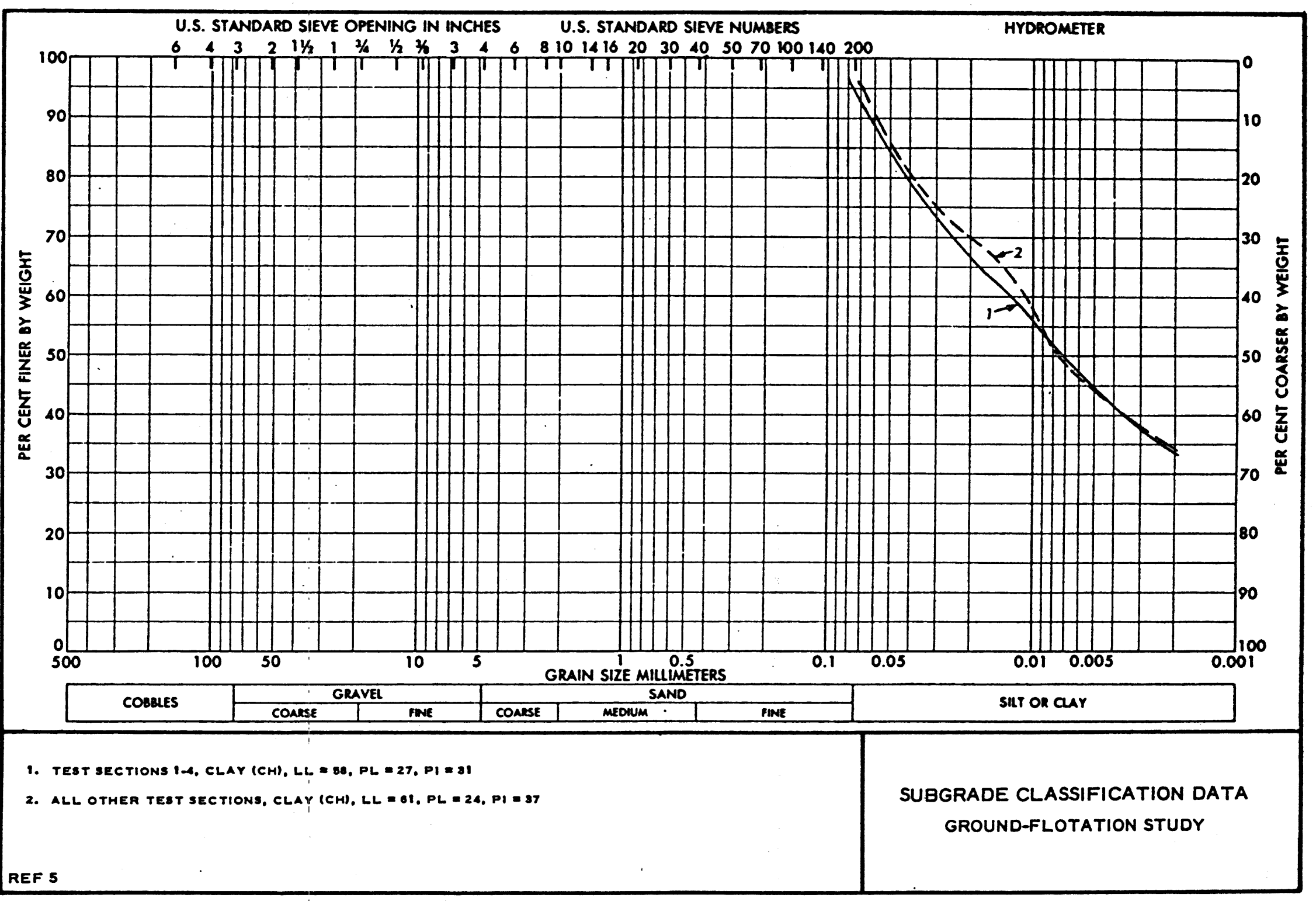




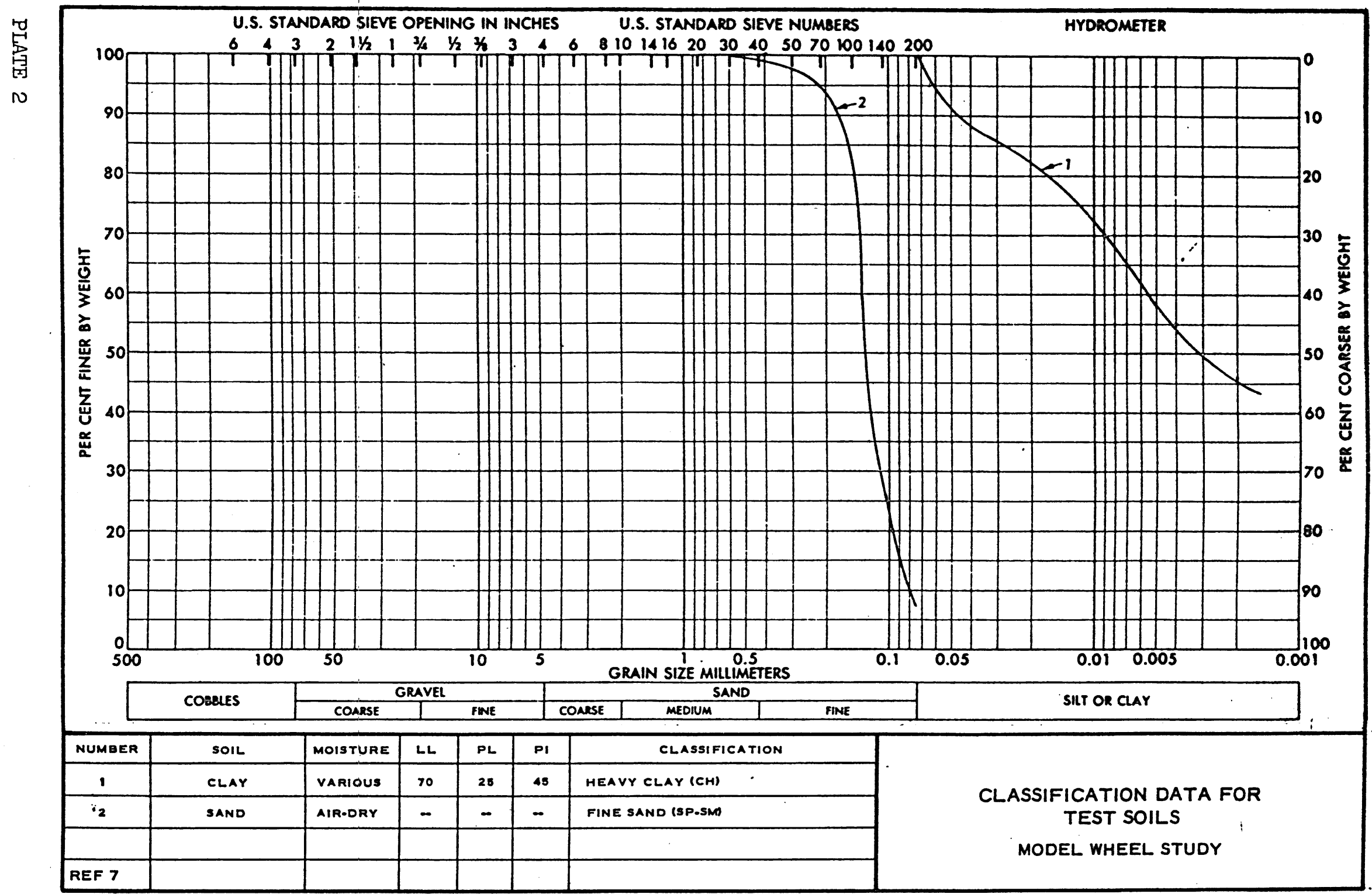




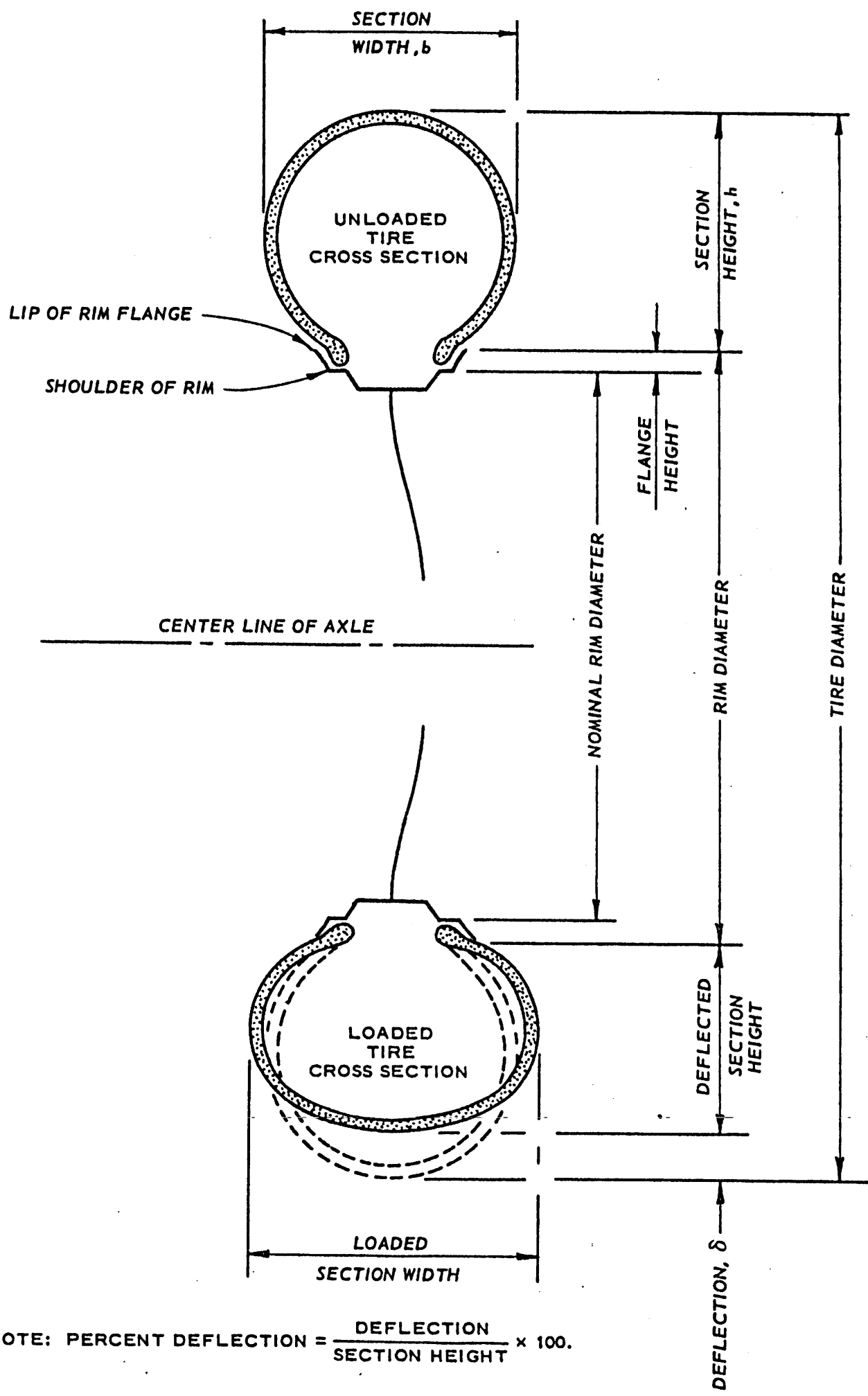

PNEUMATIC TIRE TERMS 

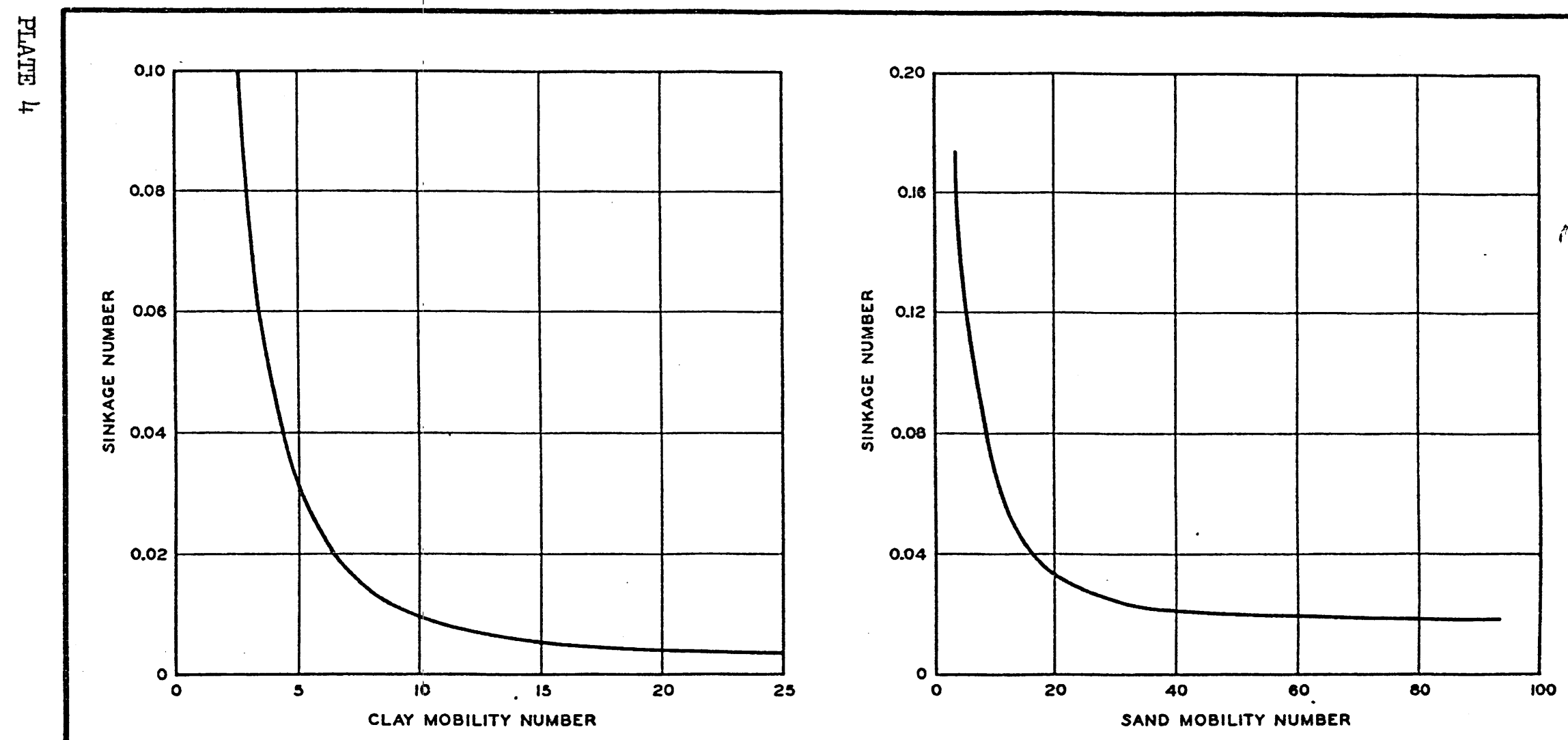

SINKAGE NUMBER VS MOBILITY NUMBER FIRST PASS 


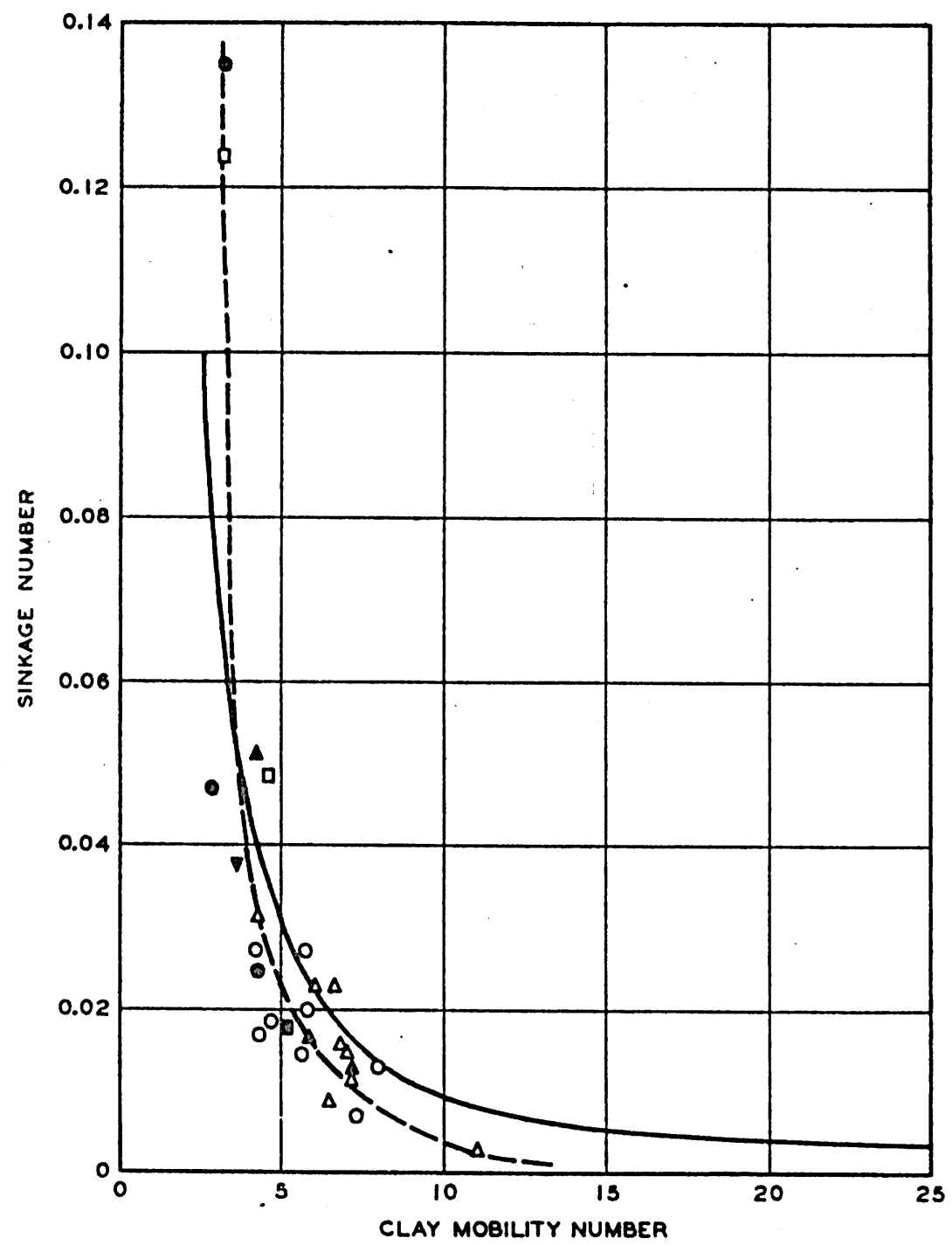

\section{LEGEND}

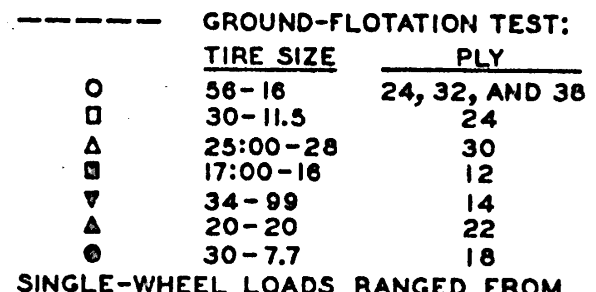

SINGLE-WHEEL LOADS

19,000 TO 35,000 LB.

AMRB MODEL STUOY

SINKAGE NUMBER VS

CLAY MOBILITY NUMBER COMPARISON STUDY 


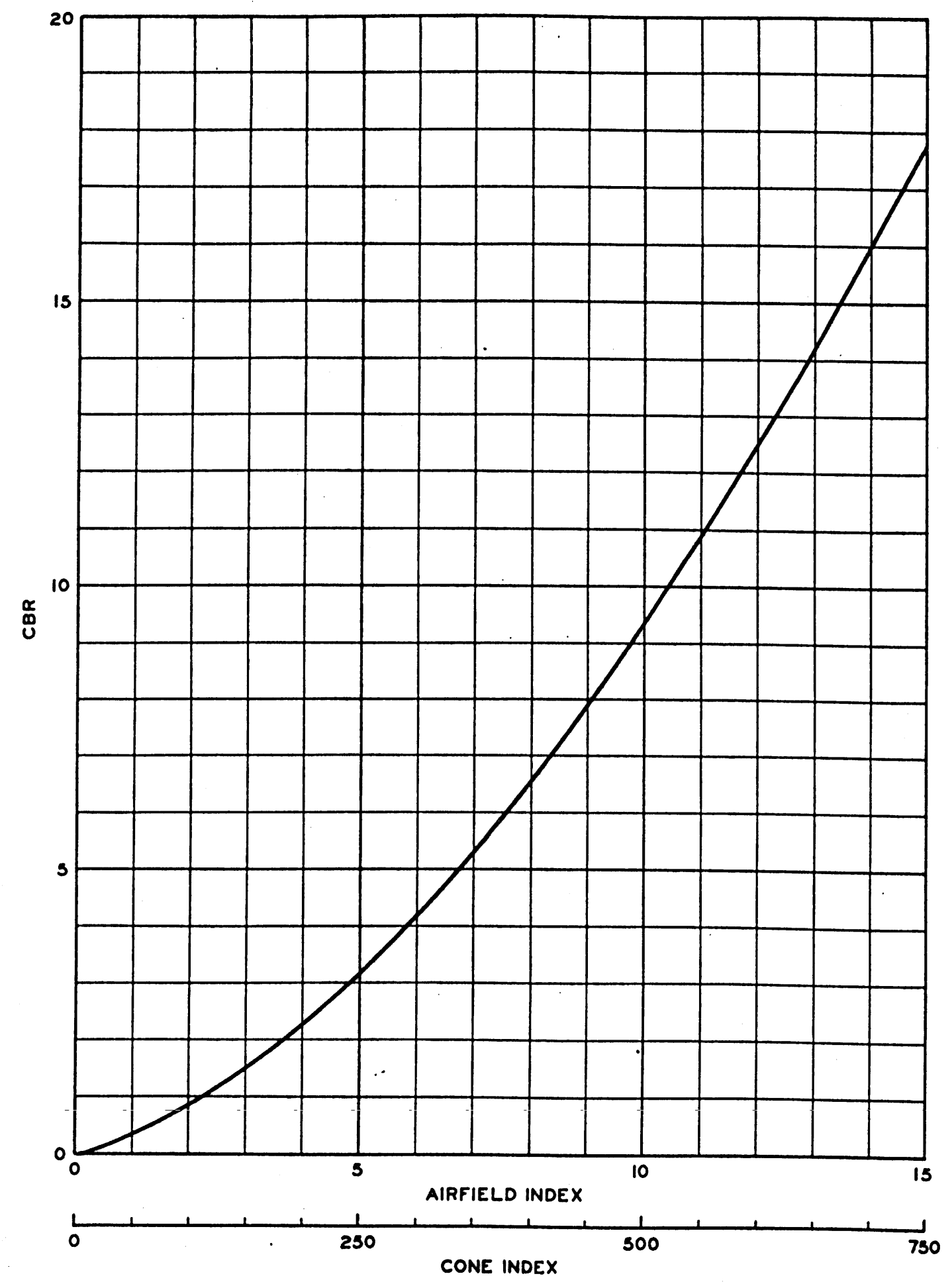

CORRELATION OF CBR AND AIRFIELD INDEX OR CONE INDEX 


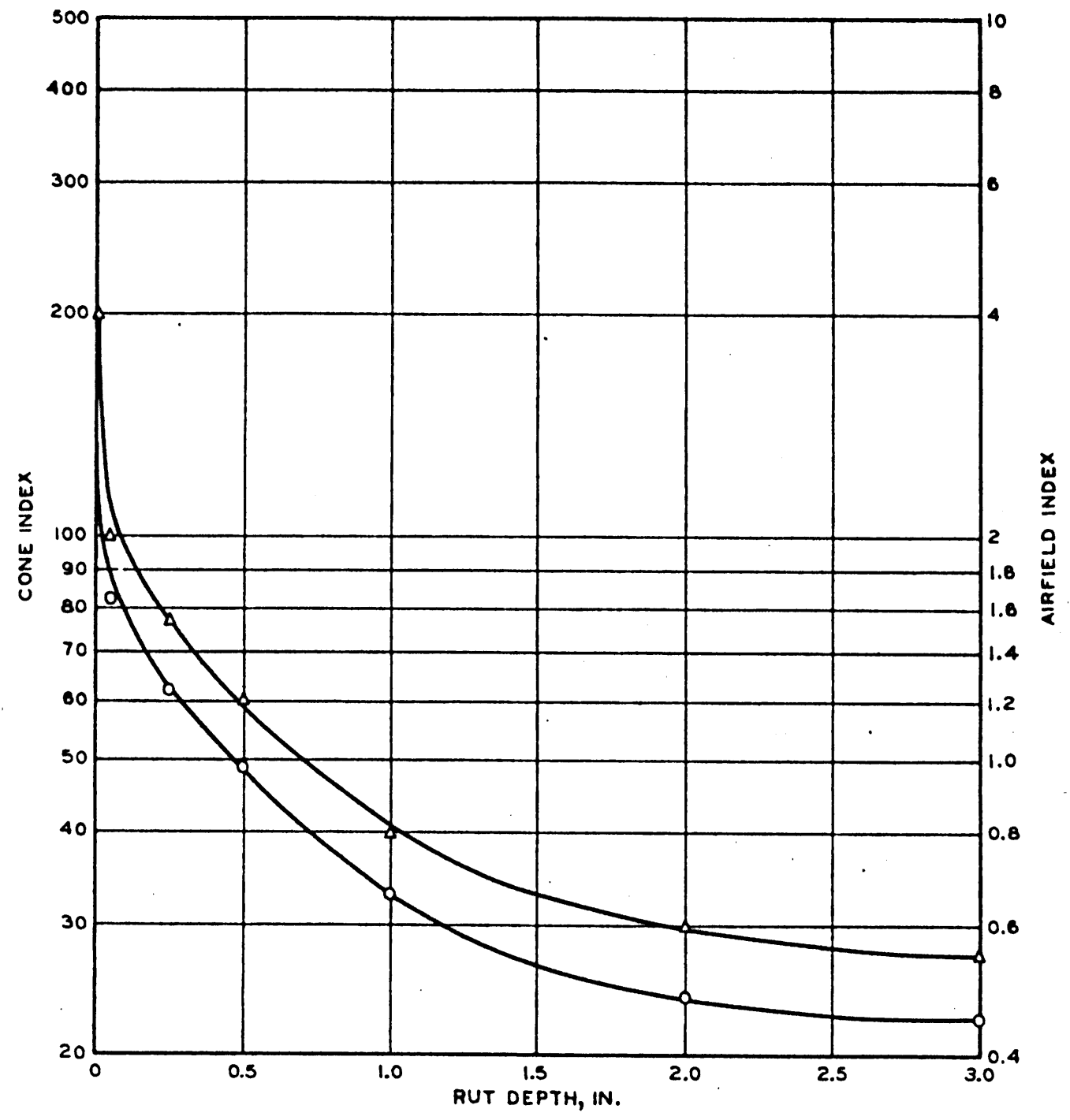

\section{LEGEND}

- EMPTY WEIGHT, 2473 LB

$\triangle$ DRIVER AND 3 PASSENGERS,

WEIGHT, 3000 LB

CONE INDEX VS

RUT DEPTH

$\frac{1}{4}$-TON, MI5I TRUCK 


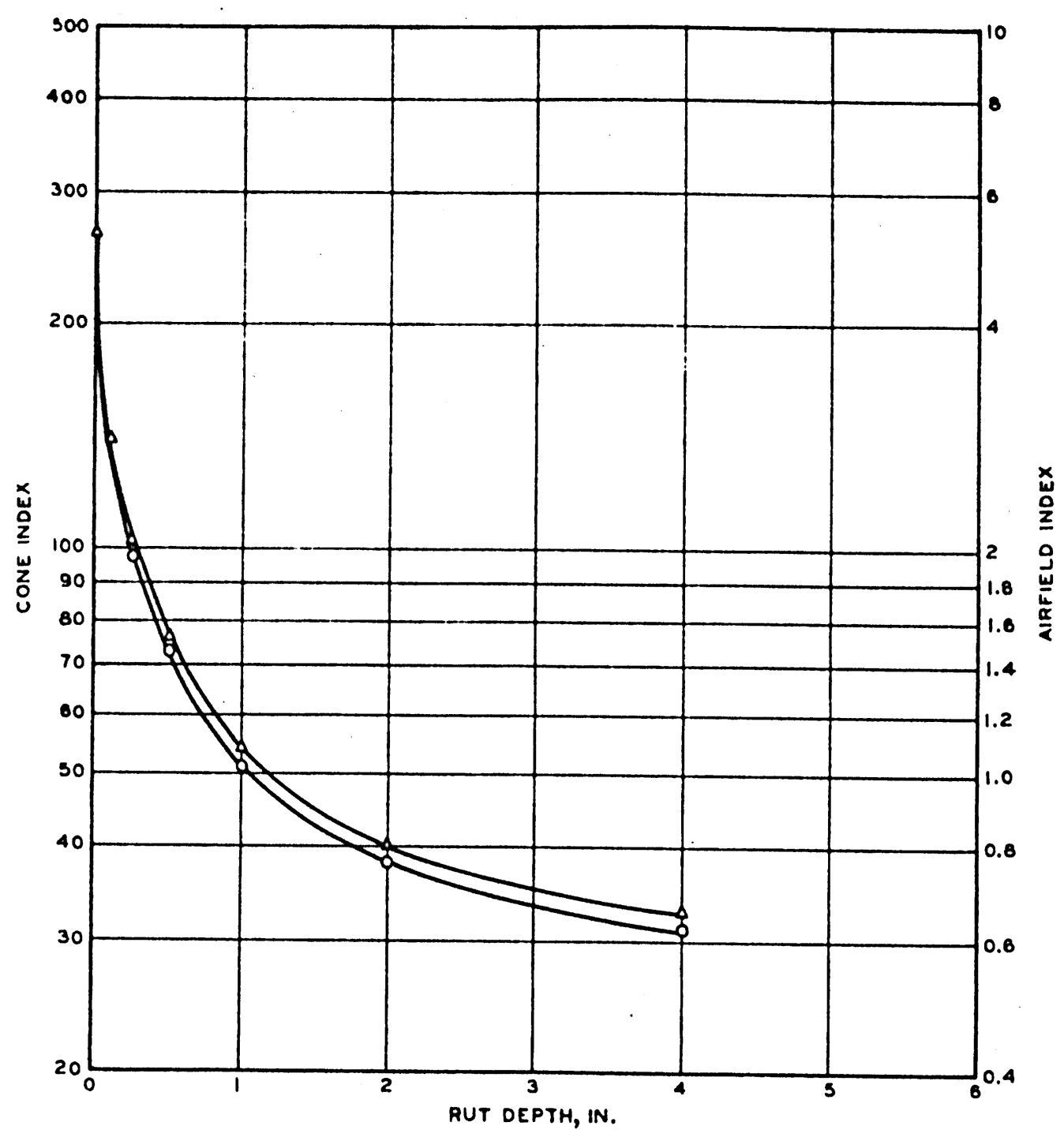

\section{LEGEND}

- O EMPTYWETGHT, 3950 LE

$\triangle$ LOADED WEIGHT, 7820 LB 


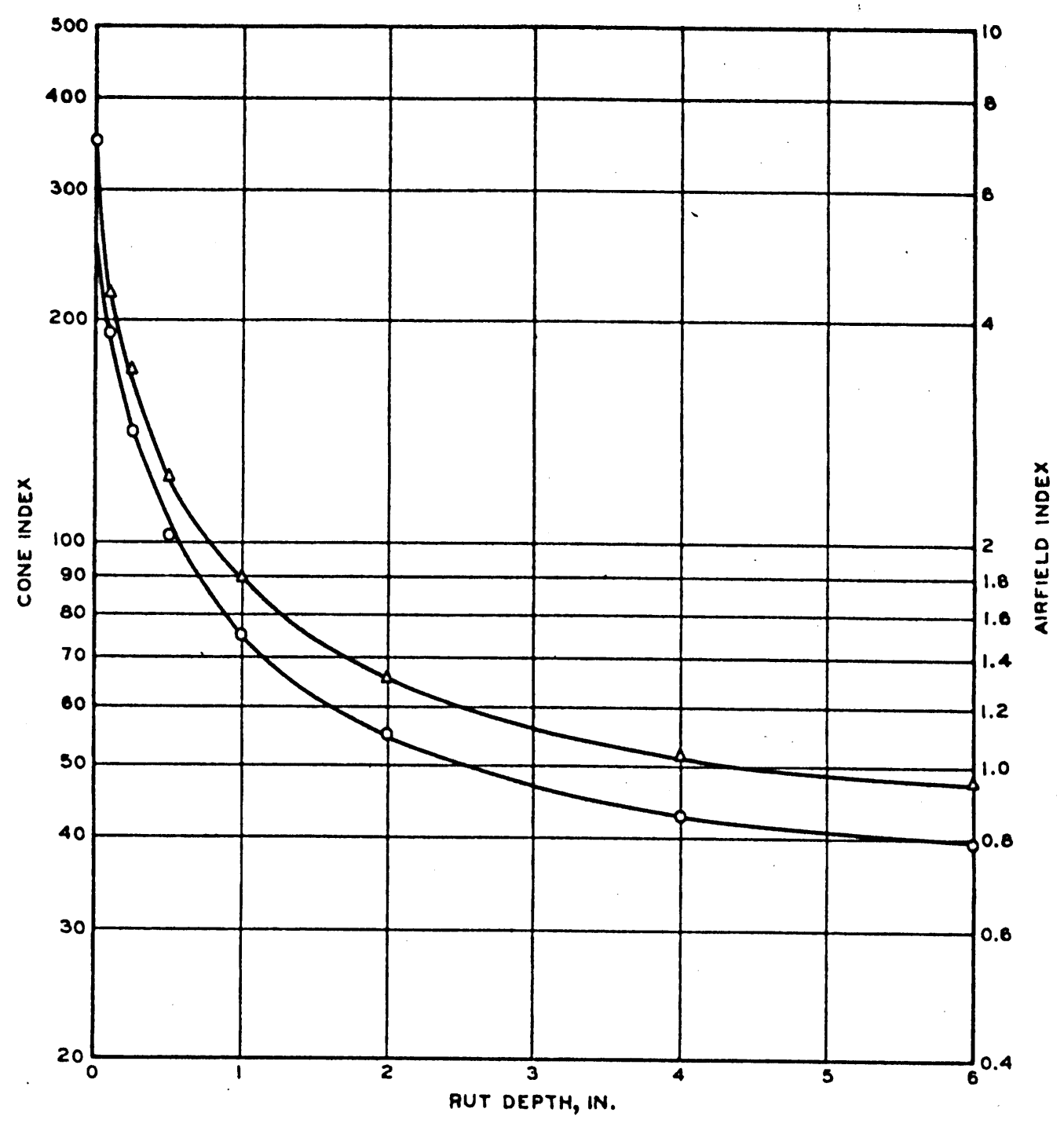

\section{LEGEND}

- EMPTY WEIGHT, 13,900 LB

$\triangle$ LOADED WEIGHT, 24,300 LB

\section{CONE INDEX VS \\ RUT DEPTH \\ $2 \frac{1}{2}-$ TON, M34 TRUCK}




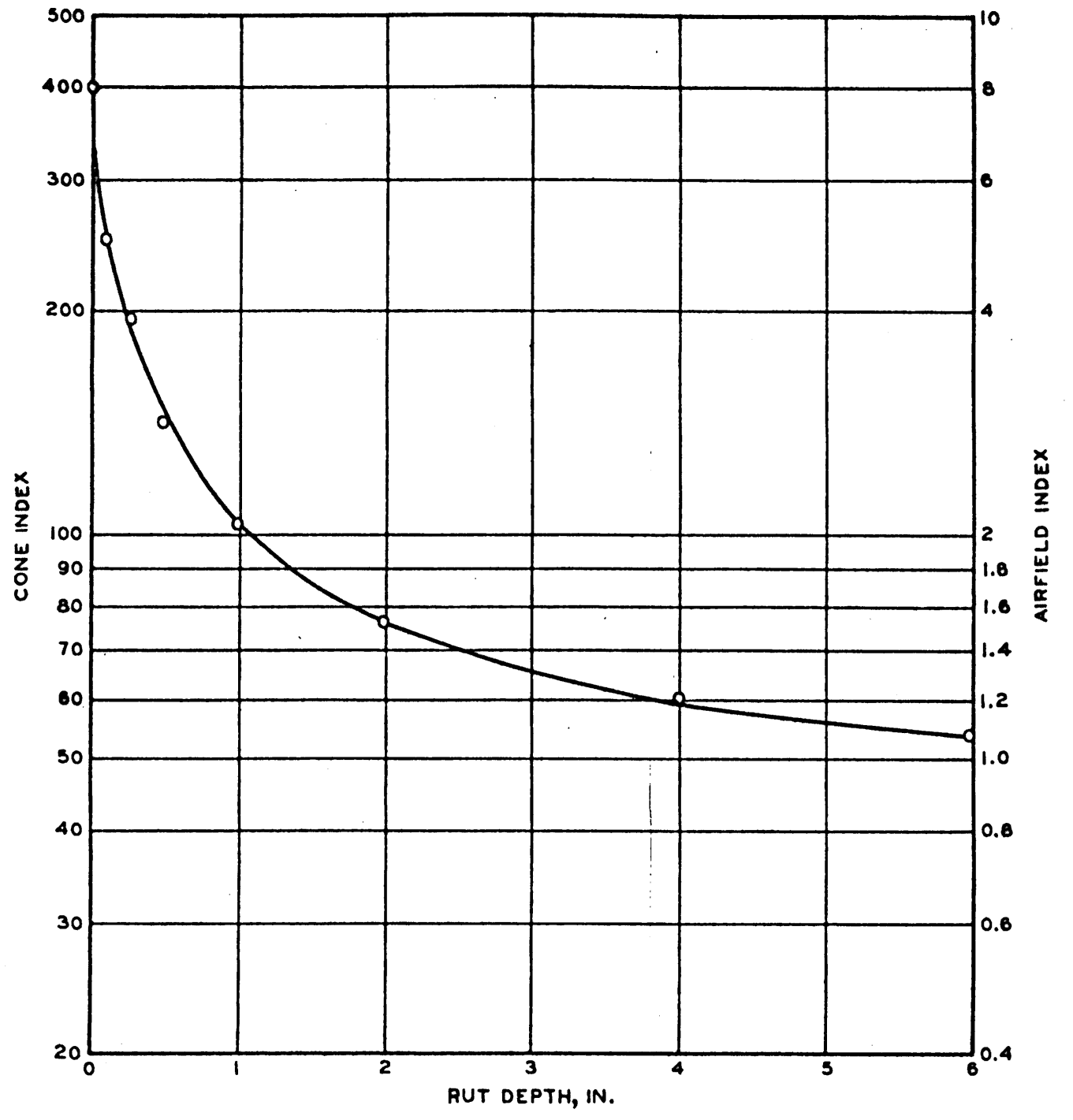

\section{LEGEND}

- eMPTY WEIGHT, 24,064 LB

CONE INDEX VS

RUT DEPTH

5-TON, M55 TRUCK 


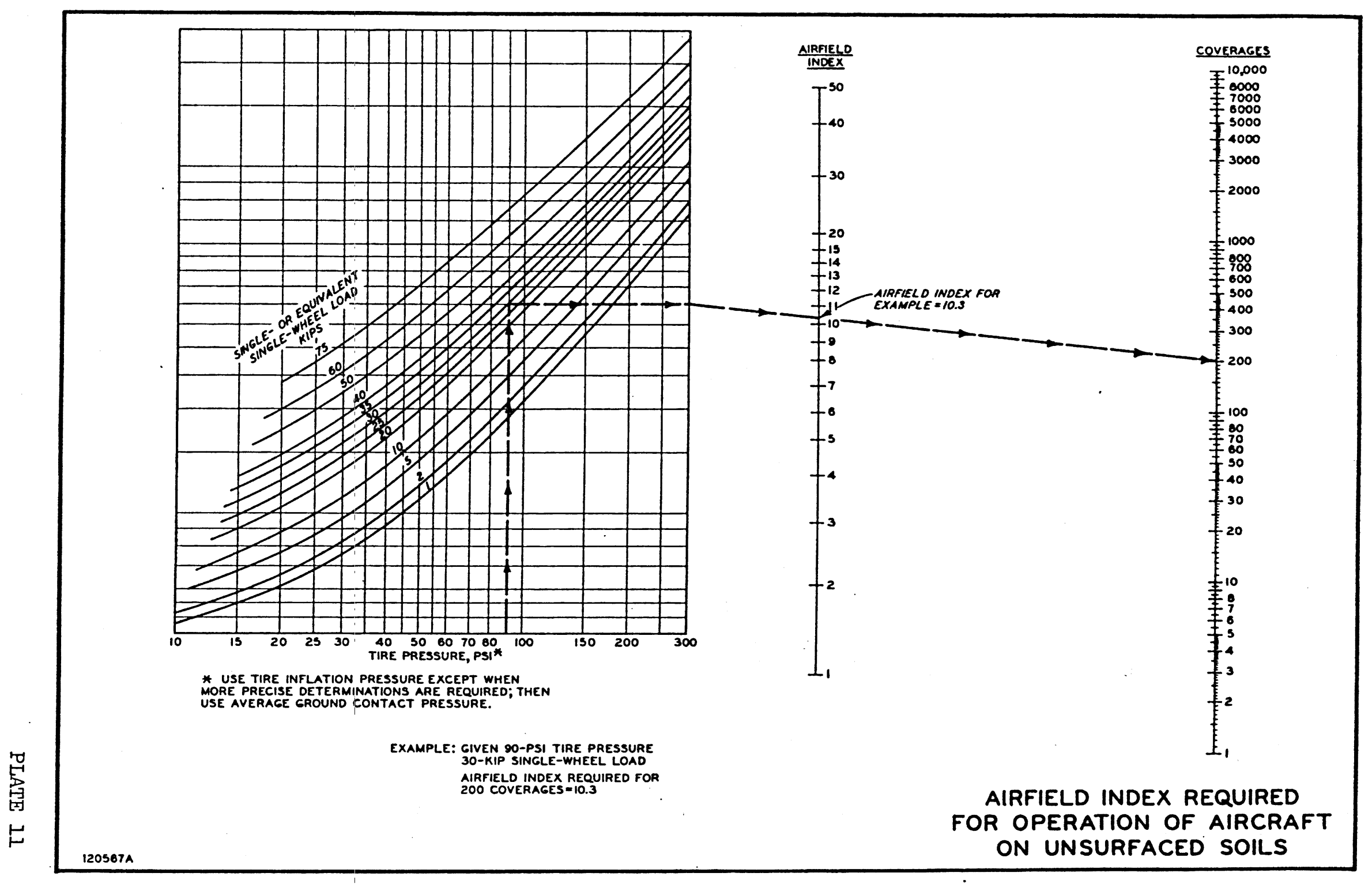




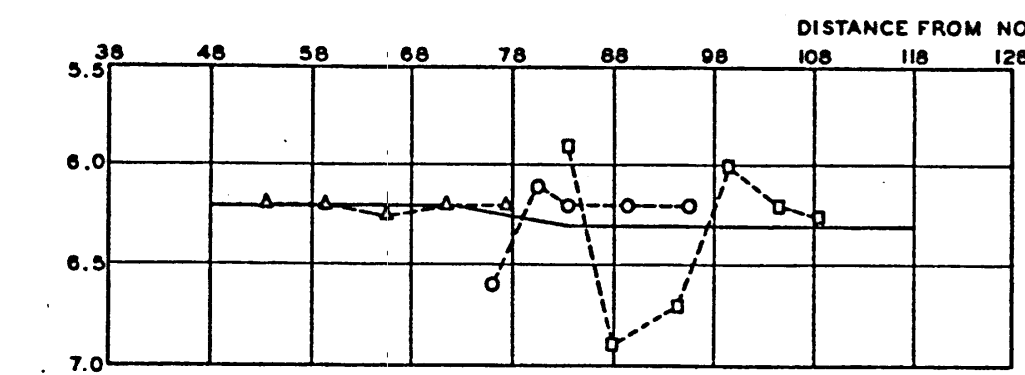$$
\text { 政 }
$$

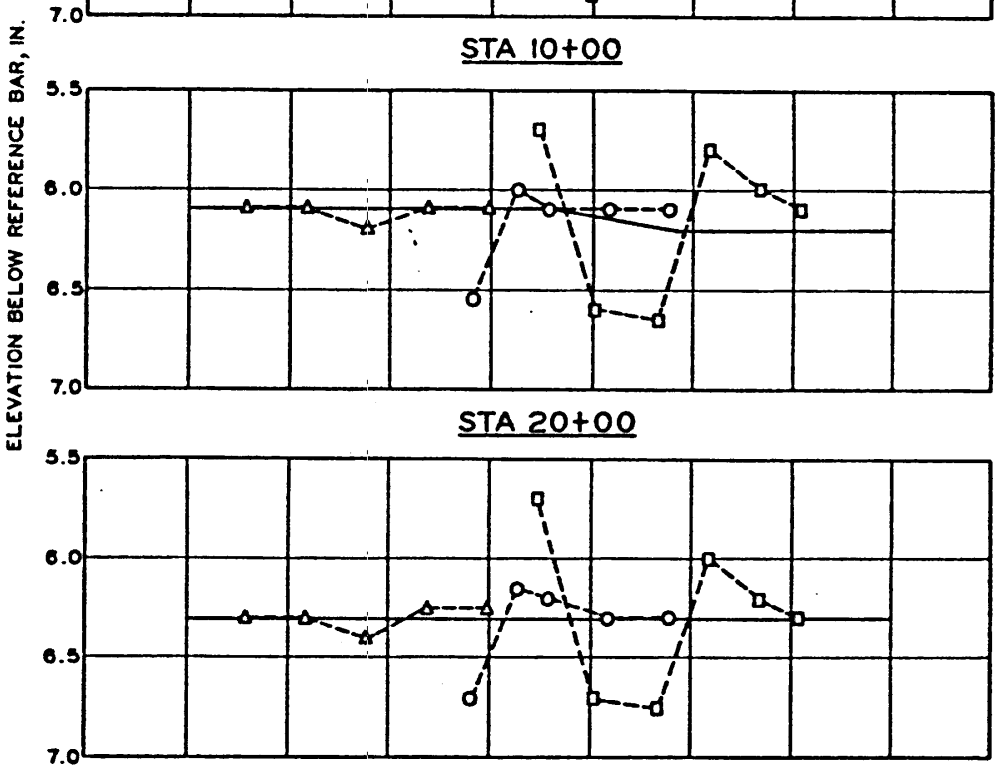

STA $30+00$

\section{LEGEND}

-- PRETRAFFic $\Delta$ MIS1

口 M35A

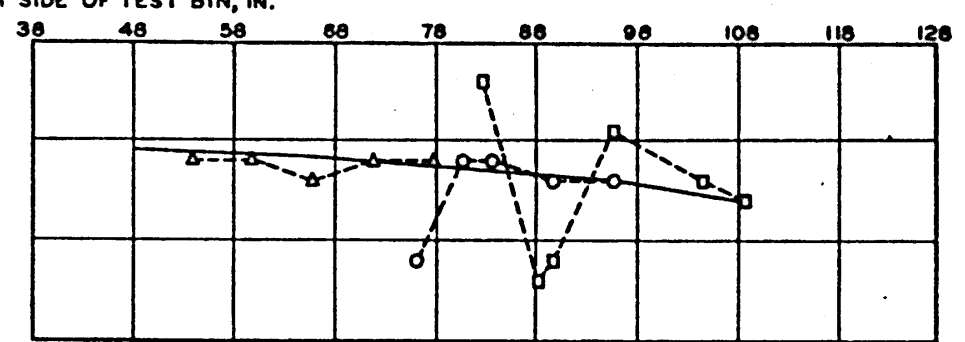

STA $15+00$

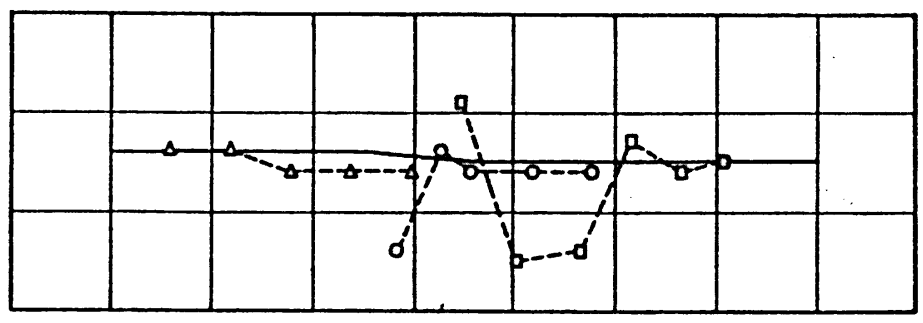

STA $25+00$

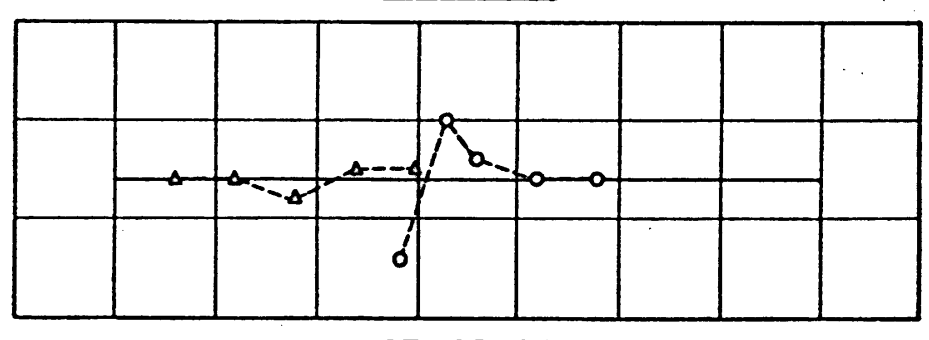

STA $35+00$

CROSS SECTIONS OF TEST SOIL PRETRAFFIC AND AFTER ONE PASS EMPTY VEHICLES 

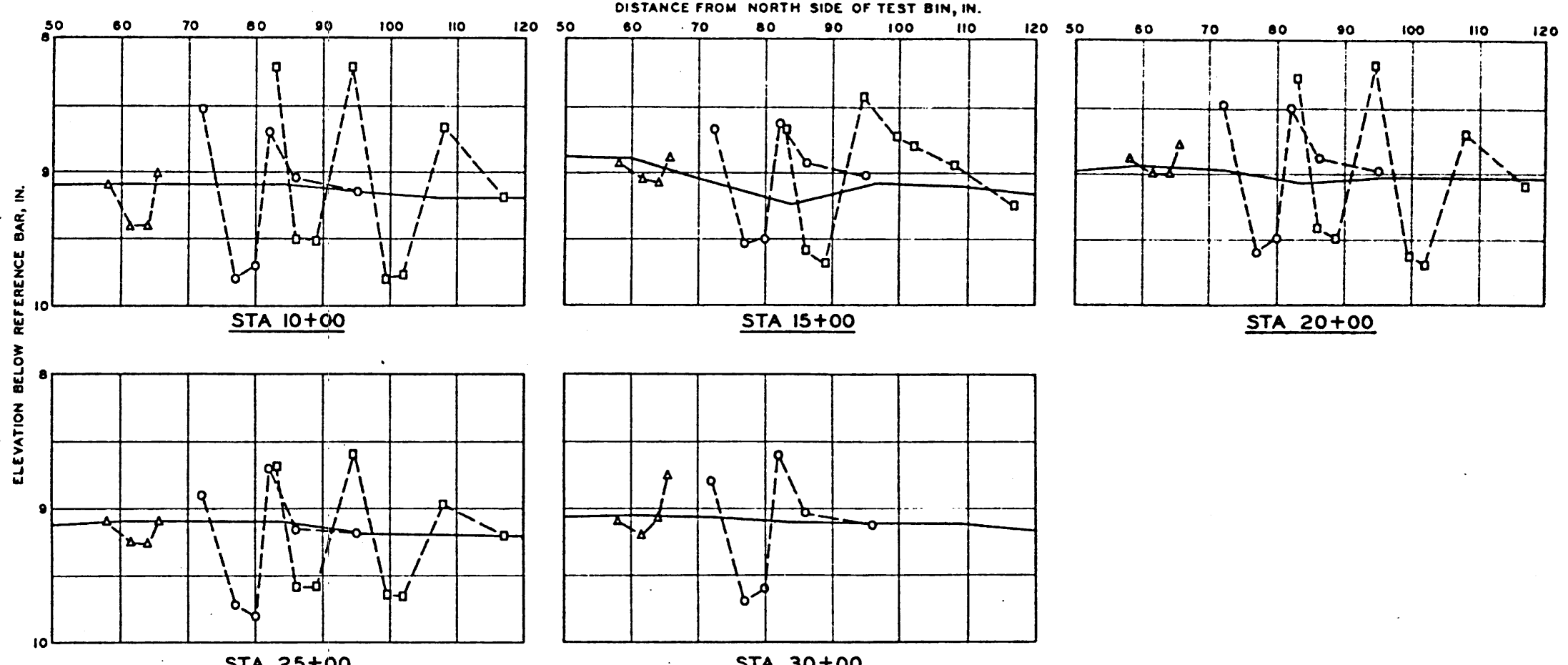

STA $20+00$ 


\section{Appendix A: Application of Soil Strength Assessment Method}

1. Table Al relates the results of the operation of several standard military ground vehicles to the requirements for operation of military aircraft on unsurfaced fields. This table was prepared as a general guide in the evaluation of soil strength of unsurfaced forward-area airfields by use of military ground vehicles. A direct evaluation can be made from table Al by applying one pass of a specific vehicle to an area, measuring the resulting rut depth, then entering the table with the measured rut depth and noting the allowable operations of specific aircraft.

2. This method of rapid soil strength assessment was developed for use on cohesive soils only. However, any rut measurement and corresponding soil strength on a cohesionless soil (sand) would be conservative for use.

3. This method of soil strength determination is meant to be a rapid indication and not a substitute for existing methods. Existing standard methods should be employed when equipment and trained personnel are available. 
TABLE A1

STANDARD MILITARY GROUND VEHICLES RELATED TO OPERATION OF MILITARY AIRCRAFT ON UNSURFACED FIELDS

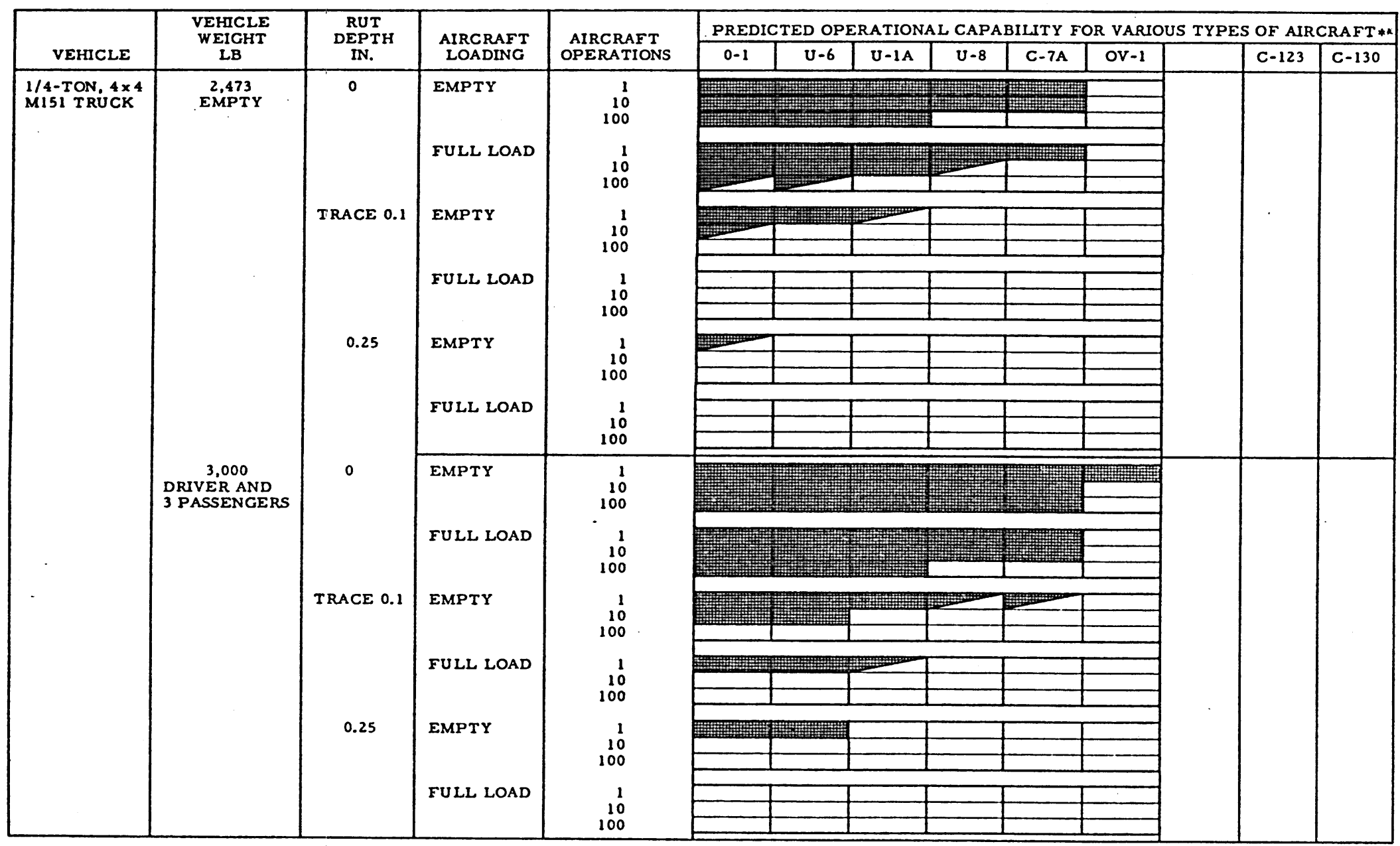

Aircraft can operate at indicated loading.

Aircraft cannot operate at indicated loading.

Aircraft may be able to operate at indicated loading with calculated risk. 
TABLE Al (Continued)

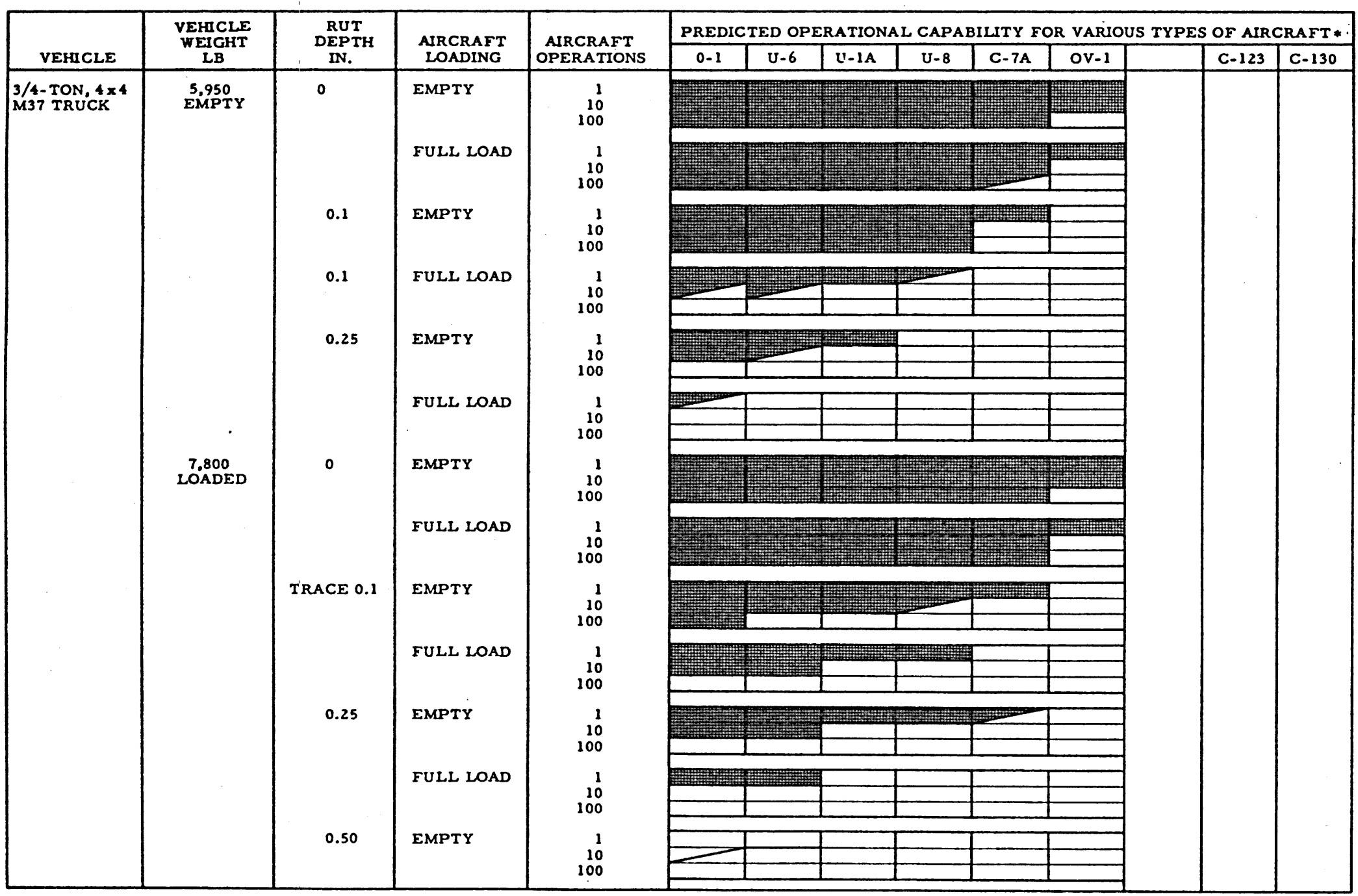

Aircraft can operate at indicated loading.

Aircraft cannot operate at indicated loading.

Aircraft may be able to operate at indicated loading with calculated risk. 
TABLE Al (Continued)

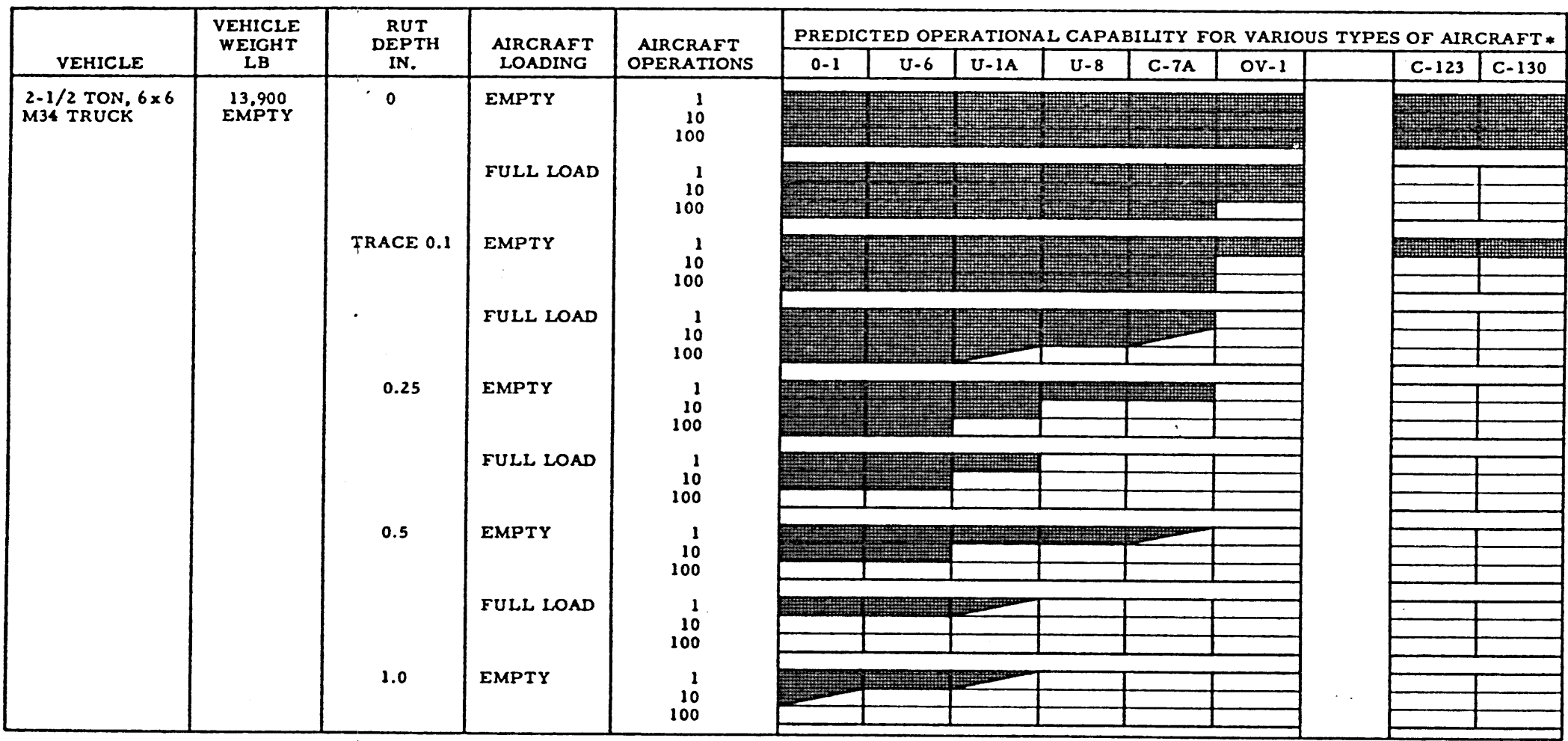

Aircraft can operate at indicated loading.

Aircraft cannot operate at indicated loading.

Aircraft may be able to operate at indicated loading with calculated risk.

3 of 5 Sheets 
TABLE Al (Continued)

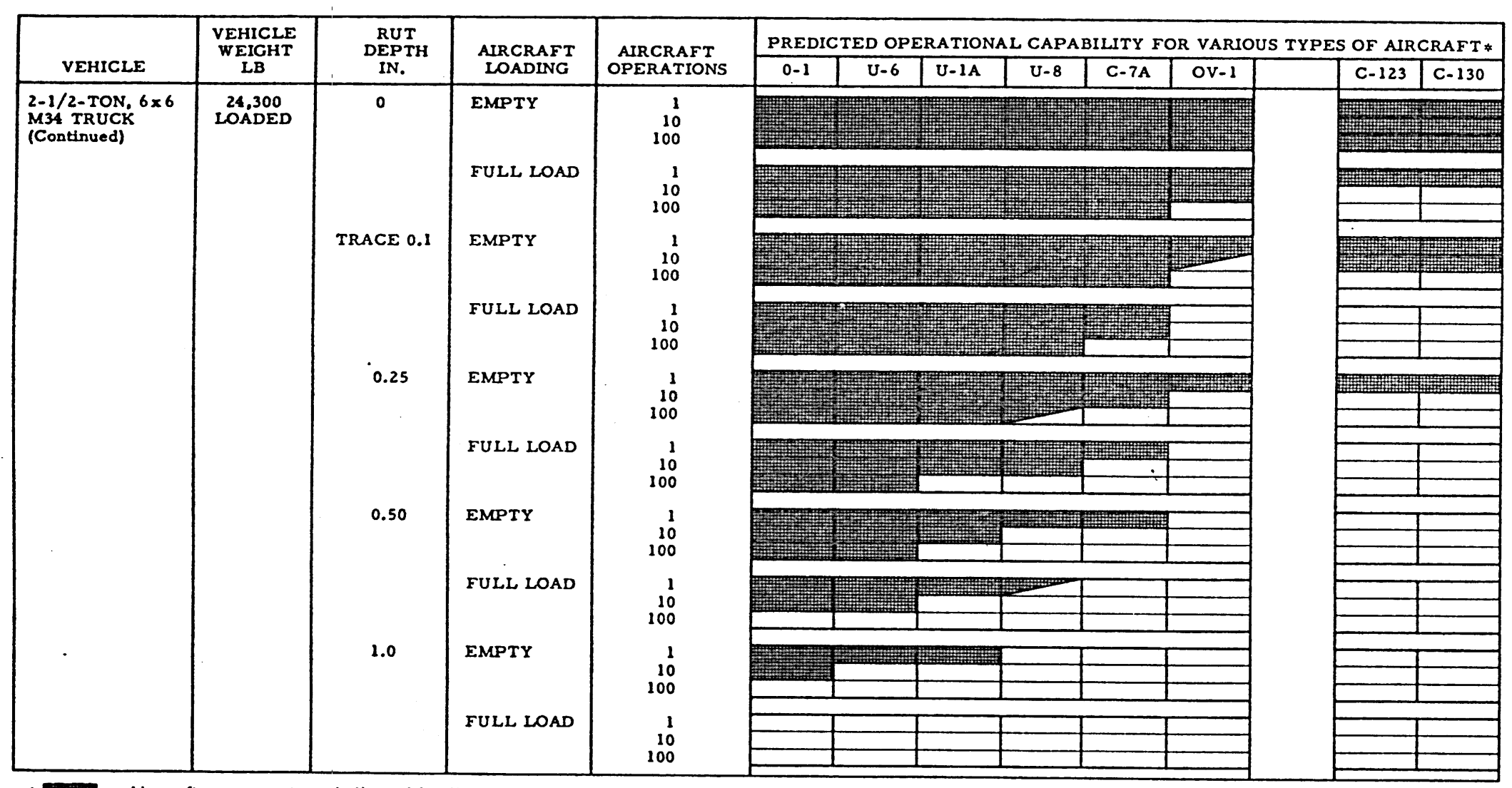

* Aircraft can operate at indicated loading.

Aircraft cannot operate at indicated loading.

Aircraft may be able to operate at indicated loading with calculated risk. 
TABLE Al (Concluded)

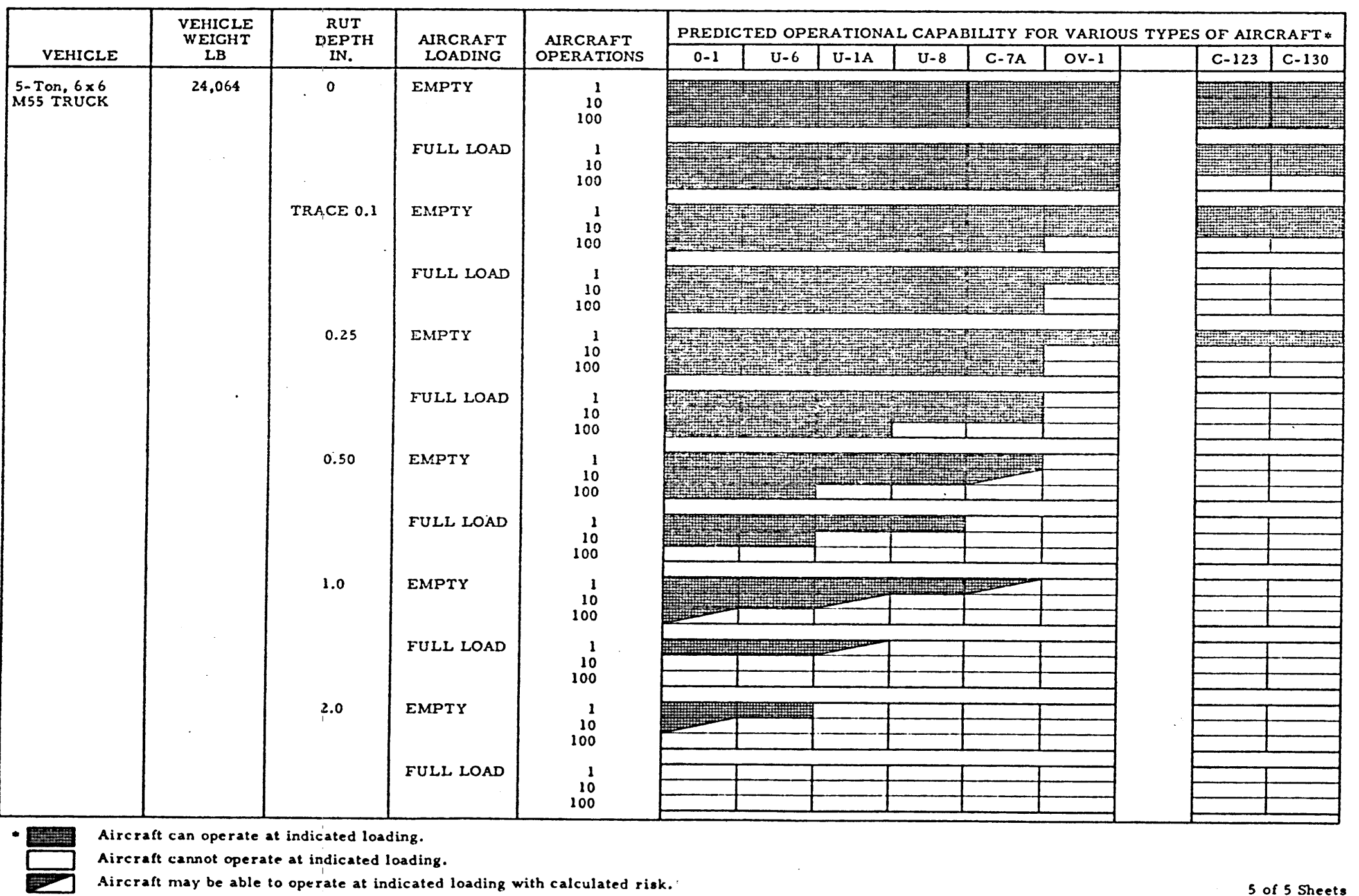


Unclassifled

Security Clessification

\section{DOCUMENT CONTROL DATA - R \& D}

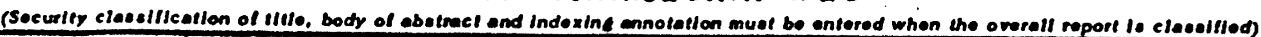
I. ORIOINA TINO ACTIVITY (Cosponeto nuthor)

U. S. Army Engineer Waterways Experiment Station

Vicksburg, Mississippi

20. nEPOAT gecuAitY CLASBIFICATION

Unclassified

2b. GNOUP

D. REPOTT TITLE

EVALUATION OF SOIL STRENGTH OF UNSURFACED FORWARD-AREA AIRFIELDS BY USE OF GROUND VEHICLES

\section{DEschID TIVE NOTES (Typo of repert end Inoluolve datoe)}

Final report

6. AU THOA(s) (Firol name, alddio InItial, laot nave)

Ceorge M. Hanmitt II

\begin{tabular}{|c|c|}
\hline $\begin{array}{l}\text { 6. MEPOAT DATE } \\
\text { May } 1970 \\
\end{array}$ & \begin{tabular}{|l|c|}
$\begin{array}{l}\text { 7a. TOTAL NO. OFPACES } \\
41\end{array}$ & $\begin{array}{c}\text { 7b. NO. OD REFS } \\
8\end{array}$ \\
\end{tabular} \\
\hline $\begin{array}{l}\text { 6. CONTRACTOR GAANT NO. } \\
\text { b. DROJECTNO. }\end{array}$ & $\begin{array}{l}\text { Da. OAIGINATOR'S REPORT NUMEER(S) } \\
\text { Miscellaneous Paper S-70-14 }\end{array}$ \\
\hline c. & 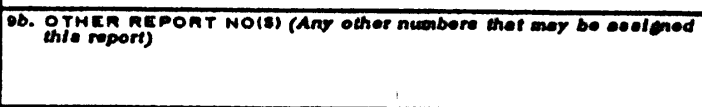 \\
\hline
\end{tabular}

10. OISTRIBUTION STATEMENT

This document has been approved for public release and sale; its distribution is unlimited.

11. SUPPLEMENTAAY NOTES

\section{ADOTACT}

This report describes a method for rapidly determining the soil strength at forwardarea airfields. Through the use of dimensionless ground mobility parameters developed by the U. S. Army Engineer Waterways Experiment Station, soil strength indications are determined by measuring rut depths created by traffic of standard military ground vehicles. This method enables reasonably accurate assessment of soil strength by personnel without special training and without the use of special instruments. If the soil strencth existing in the forward areas is known, predictions can be made concerning the ability of a particular site to sustain specific aircraft traffic. Initially, an office study was conducted that established the potential of such a method. Then limited field verification tests were conducted with four standard military ground vehicles, i.e. a 1/4-ton MIS1, a 3/4-ton M37, a 2-1/2-ton M35AI, and a 5-ton $M 55$, operated on a prepared unsurfaced heavy clay subgrade with a strength of approximately 2 CBR. First-pass rut depths were measured for each vehicle operated empty and for all but the M55 with maximum cross-country loading. The results of this testing indicated the feasibility of predicting soil strength based on onepass rut depth caused by military ground vehicles. This method can be used to predict the ability of a particular forward-area airfield to sustain specific smali aircraft traffic. It is recommended that further studies include operations of aircraft from actual landing sites on both clay and sand. 


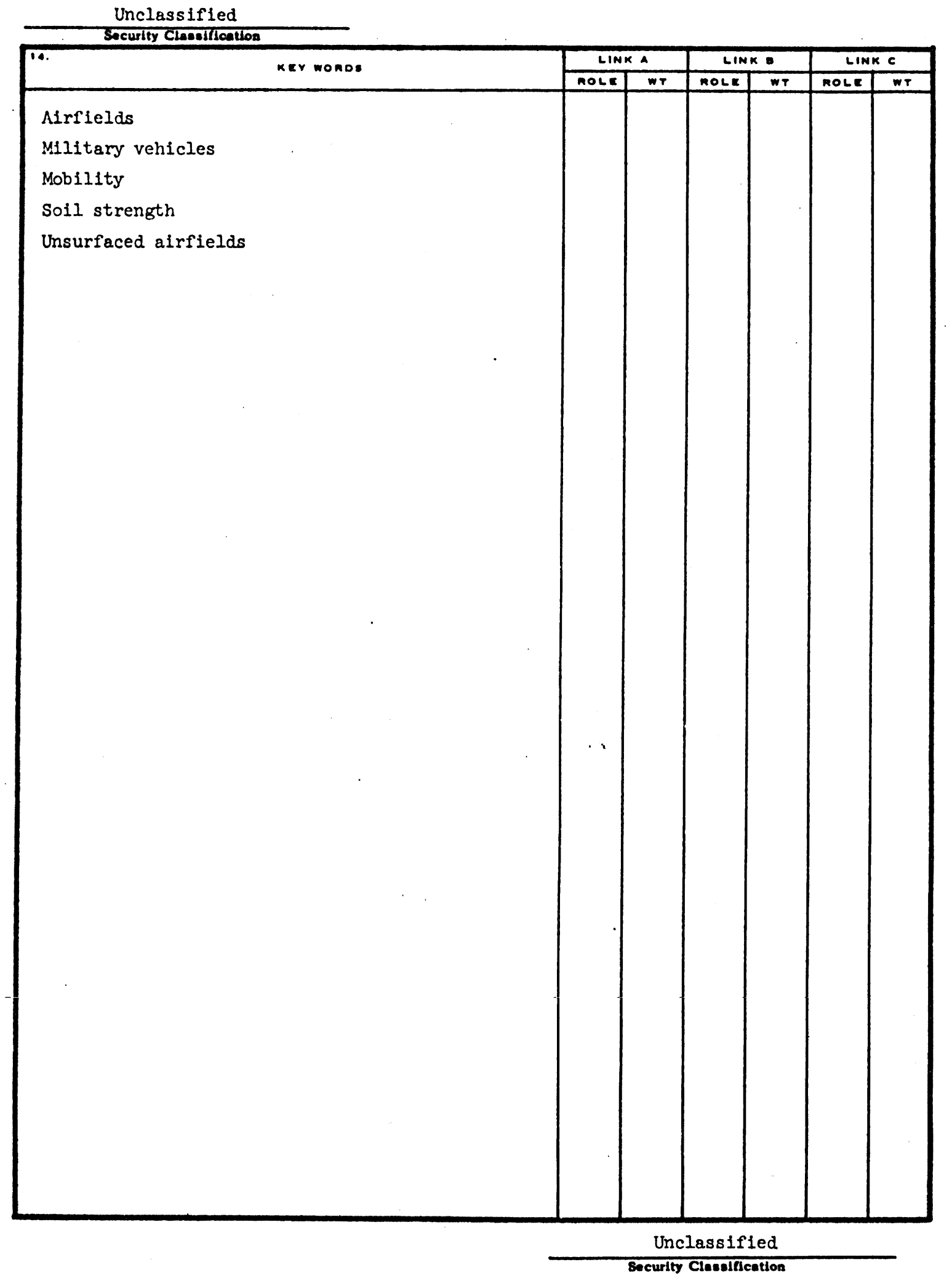

